\title{
Carbon dioxide removal through enhanced weathering of basalt on agricultural land-Assessing the potential in Austria
}

\author{
Thomas Rinder ${ }^{1}$, Christoph von Hagke ${ }^{1}$ \\ ${ }^{1}$ University of Salzburg, Department of Geography and Geology, Hellbrunner Straße 34, \\ 5020 Salzburg, Austria
}

Corresponding author: Thomas.rinder@sbg.ac.at

\section{This preprint has been submitted to the Journal of Cleaner Production and has not undergone peer review.}

\begin{abstract}
Enhanced weathering through basalt application on agricultural land represents a proposed strategy for the removal of carbon dioxide from the atmosphere. It has been shown that enhanced weathering is principally feasible on a global scale, but it remains unclear whether it can be implemented on a local level. This information is however vital, to evaluate, if enhanced weathering should be further considered as a factor to alleviate the impact of the climate crisis. With this in mind, this article reviews of the current state of research and estimates the potential for $\mathrm{CO}_{2}$ removal on regional scale through a case study for Austria. Scenarios are estimated for three different particle size distributions $(<100 \mu \mathrm{m},<10 \mu \mathrm{m}$ and $<1 \mu \mathrm{m})$. Transport related emissions may cancel out any drawdown if grain sizes $(<100 \mu \mathrm{m})$ are used. However, under optimal transport conditions the largescale application of particles with a diameter $<10 \mu \mathrm{m}$ may remove about $2 \%$ of Austria's annual Greenhouse gas emissions. We discuss challenges towards this goal, including the enormous amounts of basalt needed and the energy requirement related to grinding, as well as uncertainties related to actual field weathering rates. Those uncertainties hinder the precise quantification of $\mathrm{CO}_{2}$ drawdown as of now. While enhanced weathering remains a promising path for climate change mitigation, further research at laboratory and field scale is required to put this technology to optimal use.
\end{abstract}

Keywords: Negative emissions, basalt weathering rates, carbon dioxide removal, enhanced weathering, soil amendment 


\section{Introduction}

Within the framework of the Paris Agreement, the signing nations have agreed to keep global warming below $2{ }^{\circ} \mathrm{C}$ with respect to the pre-industrial level and to pursue efforts to limit the increase to $1.5^{\circ} \mathrm{C}$ above pre-industrial levels to mitigate the effects of human caused climate change. Estimates of the remaining global carbon budget consistent with a $1.5^{\circ} \mathrm{C}$ and $2{ }^{\circ} \mathrm{C}$ scenario imply that the annual global output of total emissions should be curbed down to $25 \mathrm{GtCO}_{2} \mathrm{e}$ (carbon dioxide equivalent) and $41 \mathrm{GtCO}_{2} \mathrm{e}$ by the year 2030, respectively (Rogelj et al. 2018). However, within the framework of current policies, the estimated annual output in 2030 will be around $60 \mathrm{GtCO}_{2} \mathrm{e}$ and even if countries manage to reach their self-determined contributions to reduce emissions, this value will only lower to about $54 \mathrm{GtCO}_{2} \mathrm{e}$ (Emissions Gap Report 2019, 2019). With the remaining carbon budget rapidly diminishing, negative emission technologies (NET) are increasingly coming into focus. Instead of reducing $\mathrm{CO}_{2}$ production, NETs focus on removing $\mathrm{CO}_{2}$ from the atmosphere and storing it in oceanic and terrestrial sinks. Current approaches include bioenergy with carbon capture and storage (BECCS), direct air capture (DAC), Enhanced Rock Weathering (EW), afforestation, ocean fertilization and the conversion of biomass into biochar for soil amendment (Negative Emissions Technologies and Reliable Sequestration: A Research Agenda, 2019; Smith et al., 2016). Large scale deployment of negative emission technologies within the $21^{\text {st }}$ century is an integral part of the vast majority of models, consistent with the $1.5^{\circ} \mathrm{C}$ and $2{ }^{\circ} \mathrm{C}$ scenario (Workman et al., 2020). These models often imply large scale removal of atmospheric $\mathrm{CO}_{2}$ by NETs only after 2050, allowing a temporal overshoot of our remaining carbon budget (Hilaire et al., 2019). It has been argued that within the framework of the current policies it might be impossible to reach the $1.5^{\circ} \mathrm{C}$ goal without relying on negative emission technologies (Anderson et al., 2020; Hickel and Kallis, 2020). Until now different NETs are at different stages of development (Anderson and Peters, 2016) and the moment there is no single solution for the removal of $\mathrm{CO}_{2}$ at scale ready for deployment (Fuss et al., 2018). This has led to a more general debate whether NETs provide promising avenues for achieving the goals of the Paris Agreement (Schlesinger and Amundson, 2019). Provided the uncertainties on a global scale and with the only alternative being a more rigorous cut in emissions, it is required to precisely quantify the future potential of NETs and how they can be incorporated into climate change mitigation scenarios (Anderson \& Peters, 2016, Fuss et al. 2014).

$\mathrm{CO}_{2}$ consumption through reaction with mafic and ultramafic rocks and minerals is one of the technologies which has already been proposed 30 years ago as an industrial process (Lackner et al., 1995; Seifritz, 1990; see Kelemen et al. (2020) for an up to date review of the topic) and the potential through diffuse spreading of rock powder to the land surface has been reviewed by Schuiling and Krijgsman, (2006). This technology is referred to as Enhanced Rock Weathering (ERW), enhanced 
weathering (EW), or Terrestrial Enhanced Weathering (TEW). We use the term EW in this study. The concept has since been investigated in a number of different scenarios. The potential of mine tailings from mafic and ultramafic deposits has been evaluated by (e.g. Assima et al., 2014, 2012; Gras et al., 2020; Hamilton et al., 2018; Harrison et al., 2013; Lechat et al., 2016; Oskierski et al., 2016; Power et al., 2020; Pronost et al., 2011; Thom et al., 2013; Wilson et al., 2014). Investigations include numerical modelling studies on global (Hartmann et al., 2013; Köhler et al., 2010; Moosdorf et al., 2014; Strefler et al., 2018; Taylor et al., 2016) and regional scale (Lefebvre et al., 2019; Renforth, 2012). While some studies focus on the application to croplands (Beerling, 2017; Haque et al., 2019; Kantola et al., 2017; Taylor et al., 2017) others focus on the marine environment and the effect of EW on ocean alkalinity (Bach et al., 2019; Hangx and Spiers, 2009; Montserrat et al., 2017; Renforth and Henderson, 2017; Rigopoulos et al., 2018a). Additonally, several field and lab studies have been carried out so far (Amann et al., 2020; Dietzen et al., 2018; Haque et al., 2020a, 2020b; Kelland et al., 2020; Renforth et al., 2015; ten Berge et al., 2012). One advantage of EW is relatively low land use compared to other NETs and low use of the resource water (Smith et al., 2016). Moreover, enhanced weathering of dunite and basalt is cost competitive with respect to other methods, ranging from 60 US $\$$ per t $\mathrm{CO}_{2}$ for dunite to 200 US $\$$ for basalt (Strefler et al., 2018). While the relatively high energy input required for EW related to mining, milling and transport of the rocks reduces efficiency, the $\mathrm{CO}_{2}$ drawdown of olivine may still reach a net value of $0.5-1 \mathrm{t} \mathrm{CO}_{2}$ per $\mathrm{t}$ of rock (Beerling et al., 2018; Moosdorf et al., 2014). Olivine is used in many studies related to $\mathrm{EW}$ for its high $\mathrm{CO}_{2}$ drawdown relative to rock mass (e.g. Dietzen et al., 2018; Renforth et al., 2015; table 1), but the potential release of toxic metals during dissolution is a disadvantage (Amann et al., 2020). In contrast, Haque and coworkers showed in a number of studies that wollastonite $\left(\mathrm{CaSiO}_{3}\right)$ amendment of soil is beneficial for crop yield, while at the same increasing soil inorganic carbon content (Haque et al., 2020b, 2020a, 2019). Similarily, basalt is already used for soil amelioration and results from an experimental study on the use of basalt powder, added to slightly acidic clay- loam soil, show cumulative removal of $4 \mathrm{t} \mathrm{CO}_{2}$ ha $^{-1}$ within 5 years (Kelland et al., 2020). This study also found an increasing crop yield (sorghum) by $21 \pm 9.4 \%$. In a recent study Beerling et al. (2020) indicated the potential of basalt application to cropland for $\mathrm{CO}_{2}$ removal on a global scale. They estimated the potential of $\mathrm{CO}_{2}$ removal for application of ground basaltic rock on cropland in the range of about 0.5 $-2 \mathrm{GtCO}_{2} \mathrm{y}^{-1}$. The aggregate amount of carbon dioxide removal, if sustained over 50 years could be between 25 and $100 \mathrm{Gt} \mathrm{CO}_{2}$. The study also showed the potential for removal of $\mathrm{CO}_{2}$ in temperate climate regions. Factors influencing the potential of EW include climate, agricultural area and practice, availability of suitable rocks, available transport networks, the $\mathrm{CO}_{2}$ intensity of electricity generation, and $\mathrm{CO}_{2}$ emissions from mining, comminution and transport. The importance of transport distance has been addressed by Lefebvre et al. (2019). The authors assessed the potential 
of basalt for EW in a part of Brazil and concluded that the maximum transport between the quarry and field would $990 \pm 116 \mathrm{~km}$, above which the transport related $\mathrm{CO}_{2}$ emissions would offset the potential $\mathrm{CO}_{2}$ capture. Therefore, if $\mathrm{EW}$ is to be used in the near future, the regional availability of suitable resources is a prerequisite and regionally tailored approaches are needed to put the technology to optimal use. Here we selected Austria as suitable case example to evaluate the feasibility of EW in a regional context. Towards the realization of the European Green Deal, countries with a relatively high share of hydropower for electricity generation, like Austria, could be well suited for EW as a technology. However, it remains to be tested whether enough basaltic rocks are available in Austria or bordering countries and whether the energy demand for mining, transport and mineral comminution and consequent $\mathrm{CO}_{2}$ production substantiate enhanced basalt weathering as a reliable strategy. In the following, we will first review the current state of research in the field before focusing on our case study.

\section{Theoretical background and methodology}

\subsection{Co-benefits from basaltic soil amelioration}

One of the goals proclaimed in the Paris agreement on climate change is to"... foster climate resilience and low greenhouse gas emissions development, in a manner that does not threaten food production". In this context, the potential co-benefits of soil amelioration through application of basaltic rocks to croplands are noteworthy. They largely contrast the societal friction points, related to competition for land use, connected to BECCS, afforestation and reforestation. In addition, EW could be co-deployed for the two latter technologies (Amann and Hartmann, 2019; Kantola et al., 2017). Application of silicate -rock fertilizers to agricultural land is not a new concept and it has been investigated already by e.g. (Hensel, 1894) or more recently by e.g. (Van Straaten, 2006). The potential benefits are linked to the fact that silicon is actively accumulated in a number of crops including wheat, barley and sugar beet (Guntzer et al., 2012). Benefits of Si are especially important under environmental stress because silicon alleviates toxicity of some toxic metals (Adrees et al., 2015), improves Potassium, Phosphor and Calcium uptake, alleviates the effects of drought and increases resistance to pathogens and insects. The recycling of plant silicon in unaltered ecosystems accounts for a high percentage in the silicon pool, owed to the re-dissolution of plant phytoliths. Under agricultural use, however, this cycle is interrupted due to the removal of crops. Especially with silicon accumulating plants this can warrant silicon fertilization (Savant et al., 1997) and a positive effect on yield has been reported for instance in the case of wheat with a grain yield increase of 4.1 $9.3 \%$ (Liang et al., 1994). Soil amendment through application of basalt has positive effects on the 
cation exchange capacity in soils and supplies Potassium, Phosphor and Calcium (Gillman et al., 2002). In addition Aluminum toxicity is a problem with acid soil conditions around the world. Silicon in general and basalt have been shown to effectively decrease Al toxicity in acid soils ( Cocker et al., 1998; Shamshuddin and Kapok, 2010). For these potential co-benefits, basaltic rock may be the best candidate for EW through application on agricultural land, despite its relatively low capability to sequester $\mathrm{CO}_{2}$, compared to dunite. Moreover release of Chromium, Nickel and Cobalt from dunite (Renforth et al., 2015; ten Berge et al., 2012) and serpentinites (Kierczak et al., 2016) and potential accumulation in soil and crops may counteract the intended soil amelioration and the same is true for low $\mathrm{Ca} / \mathrm{Mg}$ ratios (Echevarria, 2018). While serpentinites and amphiboles might exhibit good reactivity, asbestos group minerals are generally a safety concern during mining, milling, and spreading of rock powder, thereby even if handled in a safe way, public perception could impose barriers on their application (Gwenzi, 2020).

\section{$2.2 \mathrm{CO}_{2}$ drawdown through weathering}

Over geological time scales, atmospheric carbon dioxide is affected by the weathering of silicate rocks through the transformation of $\mathrm{CO}_{2}$ into $\mathrm{HCO}_{3}{ }^{-}$(Amiotte Suchet et al., 2003; Berner et al., 1983; Dessert et al., 2003; Gaillardet et al., 1999; Gislason et al., 2009; Walker et al., 1981) . For instance, the rise of the Himalayas and consequent increased weathering has resulted in $\mathrm{CO}_{2}$ drawdown and a general cooling of global climate (Raymo and Ruddiman, 1992). Similarly, past cooling phases of the climate since the Archean could be directly linked to the drawdown of $\mathrm{CO}_{2}$ from the atmosphere (e.g. Elliot Smith et al., 2008; Kump et al., 1999; Lowe and Tice, 2004). The idea behind EW is to speed up this process through grinding of rocks and targeted application to increase weathering rates. Exemplarily the chemical reaction can be followed through incongruent dissolution of anorthite (eq. 1). The dissolution of primary silicates leads to formation of secondary precipitates, releasing cations and transforming $\mathrm{CO}_{2}$ into $\mathrm{HCO}_{3}{ }^{-}$.

$\mathrm{Ca}_{2} \mathrm{Al}_{2} \mathrm{Si}_{2} \mathrm{O}_{8}+2 \mathrm{CO}_{2}+3 \mathrm{H}_{2} \mathrm{O} \rightarrow \mathrm{Al}_{2} \mathrm{Si}_{2} \mathrm{O}_{5}(\mathrm{OH})_{4}+\mathrm{Ca}^{2+}+2 \mathrm{HCO}_{3}^{-}$

Ideally the $\mathrm{HCO}_{3}{ }^{-}$ion will subsequently be transported to the ocean (Renforth and Henderson, 2017), where it possibly partially alleviates ocean acidification (Hartmann et al., 2013; Taylor et al., 2016). If supersaturation with respect to individual carbonate phases is reached, solid carbonates might form (eq. 2).

$\mathrm{Ca}^{2+}+2 \mathrm{HCO}_{3}^{-} \rightarrow \mathrm{CaCO}_{3}+\mathrm{CO}_{2}+\mathrm{H}_{2} \mathrm{O}$

Carbonate formation is an important mechanism for the in situ fixation of $\mathrm{CO}_{2}$ through Carbon capture and storage (For a review of mineral carbonation in general see e.g. Kelemen et al., 2020; 
Snæbjörnsdóttir et al., 2020). However, the aim of enhanced weathering is to convert $\mathrm{CO}_{2}$ into alkalinity, as the formation of carbonates will reduce the processes efficiency (eq. 2).

The maximum amount of $\mathrm{CO}_{2}$ drawn from the atmosphere through silicate dissolution is a function of the cation flux (mostly $\mathrm{Ca}^{2+}, \mathrm{Mg}^{2+}, \mathrm{K}^{+}$and $\mathrm{Na}^{+}$) which is charge balanced by the formation of $\mathrm{HCO}_{3}$. Drawdown potential can be expressed as the amount of $\mathrm{CO}_{2}\left(\mathrm{R}_{\mathrm{CO} 2}\right)$ removed from the atmosphere per mass of rock ( $\mathrm{t} \mathrm{CO}_{2} \mathrm{t}^{-1}$ of rock). This value might be reduced during riverine transport (Hotchkiss et al., 2015; Marx et al., 2017; Polsenaere et al., 2013) and it will further decrease, depending on the apparent carbonate equilibrium in the ocean (Beerling et al., 2020). For the relatively fast weathering of $\mathrm{Ca}$ and $\mathrm{Mg}$ bearing silicates, $\mathrm{R}_{\mathrm{cO} 2}$ is sometimes based solely on $\mathrm{Mg}^{2+}$ and $\mathrm{Ca}^{2+}$ contents (Renforth, 2012). In the case of basalt the contribution of monovalent cations $\left(\mathrm{Na}^{+}+\mathrm{K}^{+}\right)$needs to be included, as they are frequently present in basaltic rocks (see table 1 ) in the form of relatively fast weathering minerals such as nepheline (Tole et al., 1986). In addition, the calculation of R CO2 $_{\text {from incongruent }}$ dissolution, is based on the idea of Al conservation through the formation of secondary minerals (eq. 1). However, congruent dissolution of the aluminosilicate will precede the formation of the secondary phase (Maher et al., 2009; Steefel and Van Cappellen, 1990) (eq. 3) and far from equilibrium conditions can be sustained during basalt weathering for instance through complexation of $\mathrm{Al}^{3+}$ with organic acids (Perez-Fodich and Derry, 2019).

$\mathrm{Ca}_{2} \mathrm{Al}_{2} \mathrm{Si}_{2} \mathrm{O}_{8}+8 \mathrm{CO}_{2}+4 \mathrm{H}_{2} \mathrm{O} \rightarrow 2 \mathrm{Al}^{3+}+\mathrm{Ca}^{2+}+8 \mathrm{HCO}_{3}^{-}+2 \mathrm{SiO}_{2(a q)}$

Table 1 provides the $R_{\mathrm{cO} 2}$ for minerals commonly found in basalt and two different compositions of basalt (Gudbrandsson et al., 2011; Navarre-Sitchler and Brantley, 2007). Rc02 low is based on incongruent dissolution, where $\mathrm{CO}_{2}$ is charge balanced against the cations released during dissolution $\left(\Sigma \mathrm{CO}_{2}=\mathrm{meq}\left(\mathrm{Ca}^{2+}+\mathrm{Mg}^{2+}+\mathrm{Na}^{+}+\mathrm{K}^{+}\right)\right) \cdot \mathrm{R}_{\mathrm{CO} 2 \text { max }}$ is based on congruent dissolution including $\mathrm{AL}^{3+}, \mathrm{Fe}^{3+}$, $\mathrm{Fe}^{2+}$ and $\mathrm{Ti}^{4+}$ in the calculation. The latter process has also been proposed in (Navarre-Sitchler and Brantley, 2007) to asses $\mathrm{CO}_{2}$ drawdown from basalt weathering. The values of $282 \mathrm{~kg} \mathrm{t}^{-1}$ of basalt $\left(R_{\text {cO2 low }}\right)$ and $880 \mathrm{~kg} \mathrm{t}^{-1}$ of basalt $\left(R_{\mathrm{CO} 2 \mathrm{max}}\right)$ will be used for evaluation of the potential in a pessimistic and optimistic scenario in this study. 


\begin{tabular}{|l|l|c|c|c|}
\hline \multicolumn{1}{|c|}{ Name } & \multicolumn{1}{|c|}{ Formula } & g mol $^{-1}$ & Rco2 max $^{\prime}$ & Rco2 low \\
\hline Forsterite & $\mathrm{Mg}_{2} \mathrm{SiO}_{4}$ & 140.7 & 1251 & 1251 \\
Enstatite & $\mathrm{Mg}_{2} \mathrm{Si}_{2} \mathrm{O}_{6}$ & 200.8 & 877 & 877 \\
Diopside & $\mathrm{CaMgSi}_{2} \mathrm{O}_{6}$ & 216.5 & 813 & 813 \\
Hornblende & $\left(\mathrm{Ca}_{0.6} \mathrm{Na}_{0.3} \mathrm{~K}_{0.1}\right)_{2.5}\left(\mathrm{Mg}_{0.6} \mathrm{Fe}_{0.3} \mathrm{Al}_{0.1}\right)_{5}\left[\left((\mathrm{OH})_{0.75} \mathrm{~F}_{0.25}\right)_{2} /\left(\mathrm{Si}_{0.75} \mathrm{Al}_{0.25}\right)_{2} \mathrm{Si}_{6} \mathrm{O}_{22}\right.$ & 868.4 & 811 & 507 \\
Orthoclase & $\mathrm{KAlSi}_{3} \mathrm{O}_{8}$ & 278.3 & 632 & 158 \\
Anorthite & $\mathrm{CaAl}_{2} \mathrm{Si}_{2} \mathrm{O}_{8}$ & 278.2 & 1265 & 316 \\
Leucite & $\mathrm{KAlSi}_{2} \mathrm{O}_{6}$ & 218.3 & 807 & 202 \\
Nepheline & $\mathrm{Na}_{3} \mathrm{KAl}_{4} \mathrm{Si}_{4} \mathrm{O}_{16}$ & 584.3 & 1205 & 301 \\
Basalt & $\mathrm{Si}_{1} \mathrm{Ti}_{0.025} \mathrm{Al}_{0.329} \mathrm{Mg}_{0.310} \mathrm{Fe}(\mathrm{III})_{0.02} \mathrm{Fe}(\mathrm{II})_{0.193} \mathrm{Ca}_{0.273} \mathrm{Na}_{0.061} \mathrm{~K}_{0.007} \mathrm{O}_{3.394}$ & 123.5 & 968 & 429 \\
Basalt & $\mathrm{Ca}_{0.3} \mathrm{Mg}_{0.1} \mathrm{Fe}_{0.4} \mathrm{Al}_{0.3} \mathrm{SiO}_{3.25}$ & 125.0 & $\mathbf{8 8 0}$ & $\mathbf{2 8 2}$ \\
\hline
\end{tabular}

Table 1: Theoretical $\mathrm{CO}_{2}$ drawdown (Rco2 max and $\mathrm{Rcoz}_{\mathrm{cow}}$ ) in $\mathrm{kg} \mathrm{CO}_{2} \mathrm{t}^{-1}$ of rock (mineral) for common basalt forming minerals and basalt. Rco2 max is based on congruent dissolution and Rco2 low is based on incongruent dissolution. Bold numbers indicate $R_{\mathrm{CO} 2 ~ l o w}$ and $R_{\mathrm{CO} 2 \max }$ used during modelling.

\subsection{Basalt weathering rates in the context on enhanced weathering}

The dissolution of basaltic glass at far from equilibrium conditions has been investigated in mixed flow reactors by (Galeczka et al., 2014; Gislason and Oelkers, 2003; Oelkers and Gislason, 2001; Stockmann et al., 2011; Wolff-Boenisch et al., 2004). These studies show a minimum dissolution rate in the circumneutral pH area (see figure 1), commonly observed for aluminosilicates (Gautier et al., 1994; Gudbrandsson et al., 2014). In contrast, Al-free silicate minerals, such as enstatite or forsterite exhibit a near linear dependence of dissolution rates on $\mathrm{pH}$ (figure 1). Accordingly, the respective mineralogical composition of a basaltic rock may influence the stoichiometry of the released cations. This has been shown in experiments, where a $\mathrm{U}$-shaped release of $\mathrm{Ca}^{2+}$ as a function of $\mathrm{pH}$ was shown, connected to the dissolution of plagioclase, while for $\mathrm{Mg}^{2+}$ and $\mathrm{Fe}^{2+}$ dominantly released from pyroxenes and olivine a linear decrease was observed (Gudbrandsson et al., 2011). The reactivity of basalt was not hindered by the formation of secondary carbonates in the experiments carried out by Stockmann, (2011). Basaltic glass and its crystalline counterparts exhibit a similar pH dependence on dissolution rates which decrease with increasing Silicon content of the solid phase. Wolff-Boenisch et al. (2006) investigated the influence on crystallinity on dissolution rates of silicate minerals and their amorphous counterparts at $\mathrm{pH} 4$ and found that crystallinity influences the dissolution rate for Silicon rich phases, whereas ultramafic glasses dissolve similar to their crystalline counterparts. In general, dissolution rates of volcanic rocks decrease with increasing Silicon content (Wolff-Boenisch et al., 2004). 


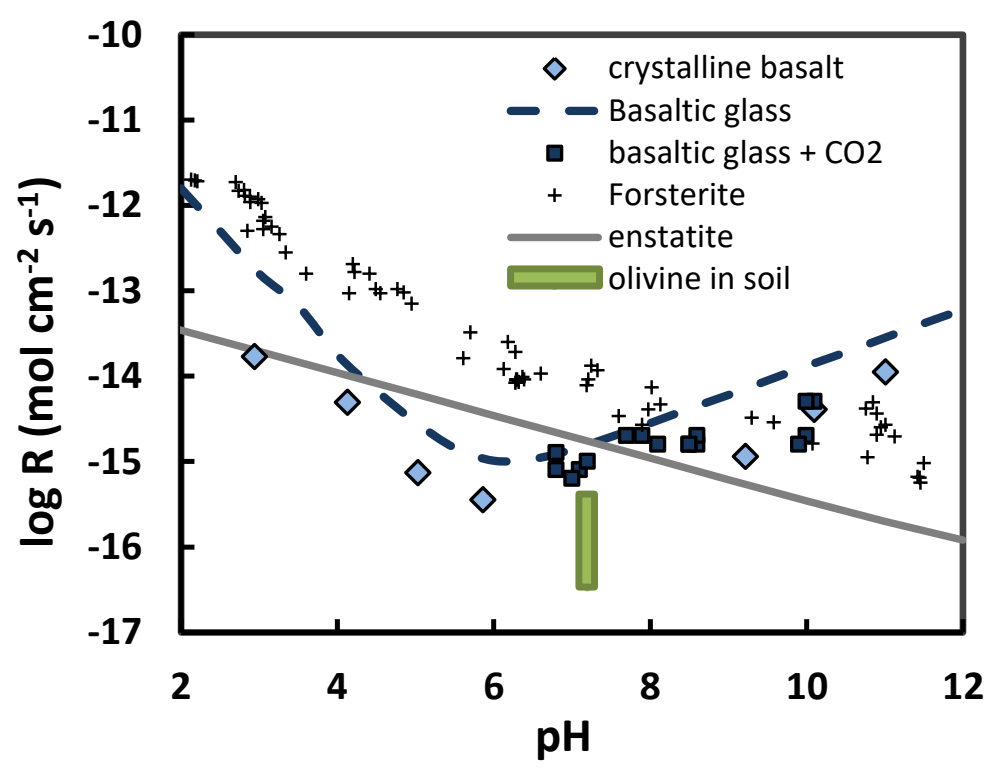

Figure 1: BET normalized dissolution rate of basalt, forsterite and enstatite (based on Silica release) as a function of $\mathrm{pH}$ at $25^{\circ} \mathrm{C}$. Crystalline basalt (Gudbrandsson et al., 2011), basaltic glass calculated from (Gislason and Oelkers, 2003), basaltic glass $+\mathrm{CO}_{2}$ (Stockmann et al., 2011), forsterite (Pokrovsky and Schott, 2000), enstatite (Oelkers and Schott, 2001) and olivine, added to soil (Renforth et al., 2015).

To understand better the importance of mafic and ultramafic rocks as reactants in the long term global Silicon Carbon cycle, basalt weathering rates have been estimated at catchment scale in several studies (e.g. Babechuk et al., 2014; Das et al., 2005; Dessert et al., 2001; Li et al., 2016; Louvat and Allègre, 1997). However, reconciling the observations from field scale with the laboratory derived weathering rates remains a challenge. In general the difference in laboratory and field rates can be attributed to both, physical i.e. hydrological features (Velbel, 1993), chemical features such as surface passivation though leached layer formation or the precipitation of secondary phases (Daval et al., 2018; Velbel, 2009), or a mixture of both, such as a long fluid residence times. The prediction of surface passivation itself is not straightforward. For instance the formation of passivating layers may be prevented through fungal biofilm, thereby increasing dissolution rates (Gerrits et al., 2020). On the other hand, the passivating effect of Al on the solubility and dissolution rate of amorphous silica and quartz has been investigated by (Bickmore et al., 2006; Iler, 1973), showing that Al containing layers not only reduce dissolution rates but also apparent overall solubility. Fluid residence time, soil moisture and mineral/fluid ratios are crucial when investigating the rate of chemical weathering (Maher, 2010; Navarre-Sitchler et al., 2011; White and Brantley, 2003). The complex interrelationship between gas and water in the unsaturated zone further complicates the calculation of realistic weathering rates (Harrison et al., 2017, 2015). In addition, field weathering 
rates are influenced by trace metals (Oelkers et al., 2018), bacterial communities (Wild et al., 2019) or organic ligands (Perez-Fodich and Derry, 2019; Perez et al., 2015). They are not only dependent on a specific surface area but can be influenced by crystallographic orientation of minerals (Daval et al., 2013).

In the context of enhanced weathering, dissolution of rock powder added to soil cannot be calculated merely based on dissolution rates. The shrinking core model has been used to describe the time for complete dissolution of a grain (Hangx and Spiers, 2009). The authors estimated that the addition of olivine to seawater requires particle sizes $<10 \mu \mathrm{m}$ to achieve relatively complete dissolution of 100 years. With a similar approach Renforth et al. (2015) estimated that the particle size of olivine added to soil, would have to be in the range of $0.1-0.01 \mu \mathrm{m}$ to dissolve within 5 years.

Notwithstanding the uncertainties related to field weathering, in this study dissolution was calculated, using a dissolution rate from (Gudbrandsson et al., 2011), who measured a BET normalized rate of $3.5510^{-12} \mathrm{~mol} / \mathrm{m}^{2} / \mathrm{s}$ at pH 5.84 and $25^{\circ} \mathrm{C}$ (see figure 1). This is probably at the high end of weathering rates, given the discrepancy between lab and field rates and $25^{\circ} \mathrm{C}$ is certainly far away from the annual average temperature in Austria. It is however close to the high end of dissolution rates reported for olivine in soil by (Renforth et al., 2015) (see figure 1) and it is also in the range of the elemental release rates reported for basalt added to soil (Kelland et al., 2020). These authors measured an elemental $\mathrm{Mg}$ release rate of $6.6 \times 10^{-13} \mathrm{~mol} \mathrm{~m}^{-2} \mathrm{~s}^{-1}$ and a Ca release of $2.8 \times 10^{-}$ ${ }^{12} \mathrm{~mol} \mathrm{~m}^{-2} \mathrm{~s}^{-1}$. For comparison, the stoichiometric dissolution of our model basalt (table 1) at the chosen rate gives an elemental release rate for $\mathrm{Mg}$ of $3.54 \times 10^{-13} \mathrm{~mol} \mathrm{~m}^{-2} \mathrm{~s}^{-1}$ and $1.06 \times 10^{-12} \mathrm{~mol} \mathrm{~m}^{-2}$ $\mathrm{s}^{-1}$ for Ca.

The BET surface area of the model basalt was calculated using an empirical equation, provided in (Brantley and Mellott, 2000) for olivine, where $d$ is the particle diameter.

$\log S S A\left(\mathrm{~cm}^{2} / \mathrm{g}\right)=5.3-1.1 * \log (d)$

Molecular weight of the basalt is $125 \mathrm{~g} / \mathrm{m}^{2}$ and the density is assumed $3 \mathrm{~g} / \mathrm{cm}^{3}$. To apply the shrinking core model, based on spherical particles the BET normalized ratio has to be recalculated for geometric surface. Toward this goal the geometric surface area $\left(\mathrm{SSA}_{\text {geo }}\right)$ of spherical grains of each fraction was calculated according to the equation provided in (Tester et al., 1994). The roughness ratio $\left(\mathrm{SSA}_{\mathrm{BET}} / \mathrm{SSA}_{\mathrm{Geo}}\right)$ was then used to recalculate the dissolution rates based on geometric surface area (see the supplementary file for details about the calculation). 


\subsection{Geographical framework and model parameters}

\subsubsection{Availability of volcanic rocks in Austria and neighboring countries}

Potential occurrences of volcanic rocks in the vicinity of Austria comprise units from the Western and Central European volcanic province in the Massif Central (Lustrino and Wilson, 2007), the Bohemian Massif and Eger Graben (Ulrych et al., 2011), Germany (Jung et al., 2005; Jung and Masberg, 1998), the Pannonian-Carpathian Volcanic province - parts of which are based in SE Austria (Ali et al., 2013; Downes et al., 1995; Lukács et al., 2018; Seghedi et al., 2004) and the Veneto Volcanic province in Northern Italy (Peccerillo, 2005) as well as some occurrences in the Dinaric alps (Prelević et al., 2005), (see figure 2).

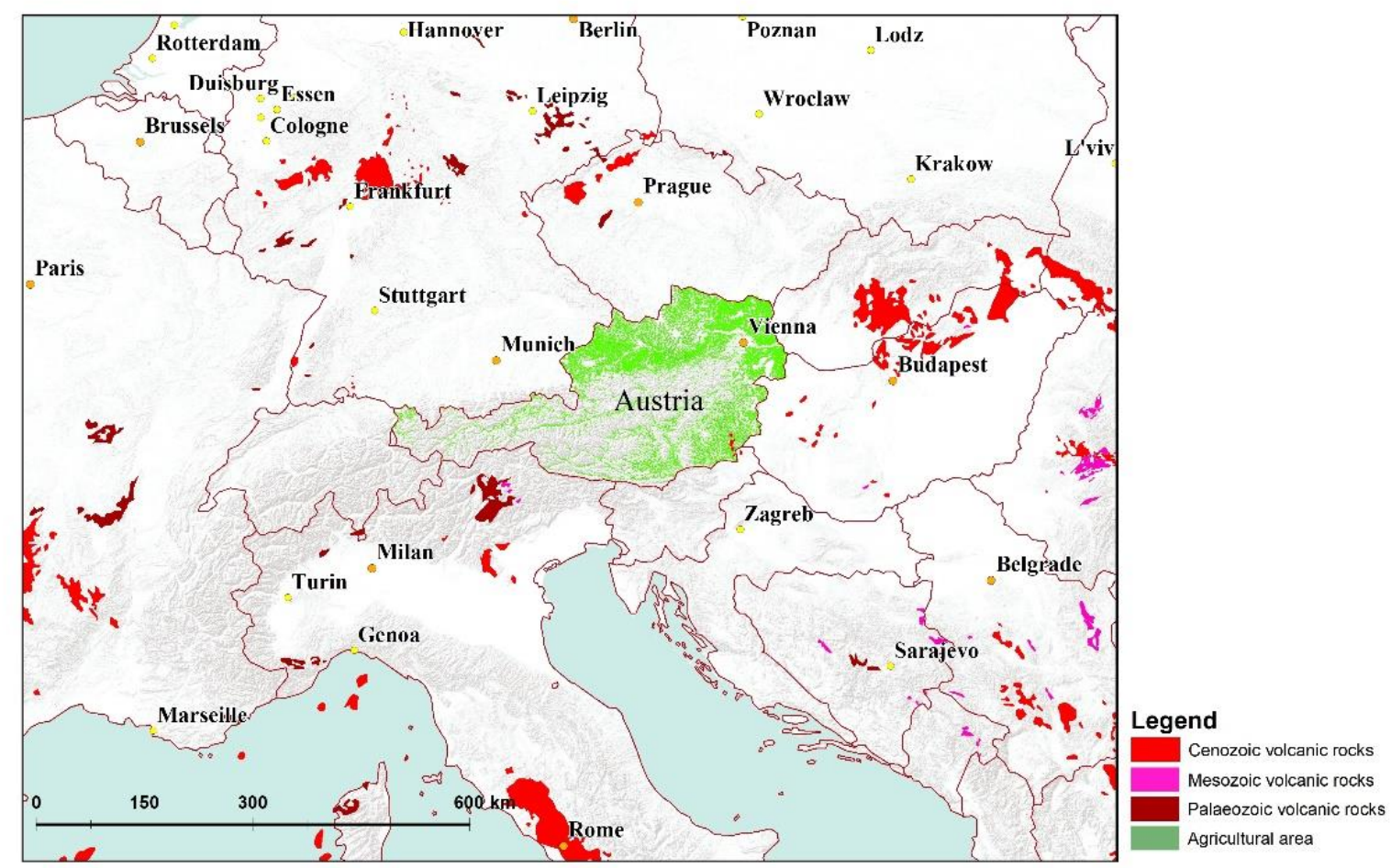

Figure 2: Map showing the distribution of agricultural land in Austria and potential volcanic rocks in the wider vicinity. Layers: World terrain basemap (Sources: Esri, USGS, NOAA); World cities (Sources: Esri; Bartholemew and Times Books; U.S. Central Intelligence Agency (The World Factbook); International Organization for Standardization; United States Department of State, Bureau of Intelligence and Research; GeoNames; Executive Secretary for Foreign Names - U.S. Board on Geographic Names; U.S. National Geospatial-Intelligence Agency; BBC News; Global Mapping International); CORINE land cover 2018 (@ Umweltbundesamt \& European Union, Copernicus Land Monitoring Service 2018, European Environment Agency (EEA), with funding by the European Union); (C) EuroGeographics for the administrative boundaries; volcanic rocks from IGME-5000 (Asch, 2005). The map was created using ArcGIS ${ }^{\circledR}$ software by Esri. ArcGIS ${ }^{\circledR}$ and ArcMap $^{T M}$ are the intellectual property of Esri and are used herein under license. Copyright (C) Esri. All rights reserved. 
Relatively large volcanic provinces of Permo-Carboniferous origin appear south of the Insubric line, mostly comprising intermediate to felsic volcanic rocks, e.g. dacite, trachyte, rhyolite (Cortesogno et al., 1998). The same is true for relatively large volcanic fields close in the West Carpathians, such as the central Slovakian volcanic field, mostly comprising andesite (Chernyshev et al., 2013). Similarly, volcanic rocks of the roman volcanic province are largely of intermediate composition (Beccaluva et al., 1991). (Plata et al., 2021) investigated the potential of andesitic and dacitic mining waste as a soil fertilizer, showing that soil amelioration is not limited to volcanic rocks with a low Si content. However, Cenozoic volcanic rocks of ultramafic to mafic composition can be found in all volcanic provinces surrounding Austria (see figure 3). The impression gained from figure 3 also holds when being compared to the more extensive database of volcanic rocks provided in (Lustrino and Wilson, 2007) or with respect to the data given by (Hartmann and Moosdorf, 2012), who calculated the percentage for basic volcanic rocks of appr. $59.5 \%$, with intermediate compositions contributing $8.5 \%$ and acid compositions covering an area of $32 \%$ for whole Europe. 

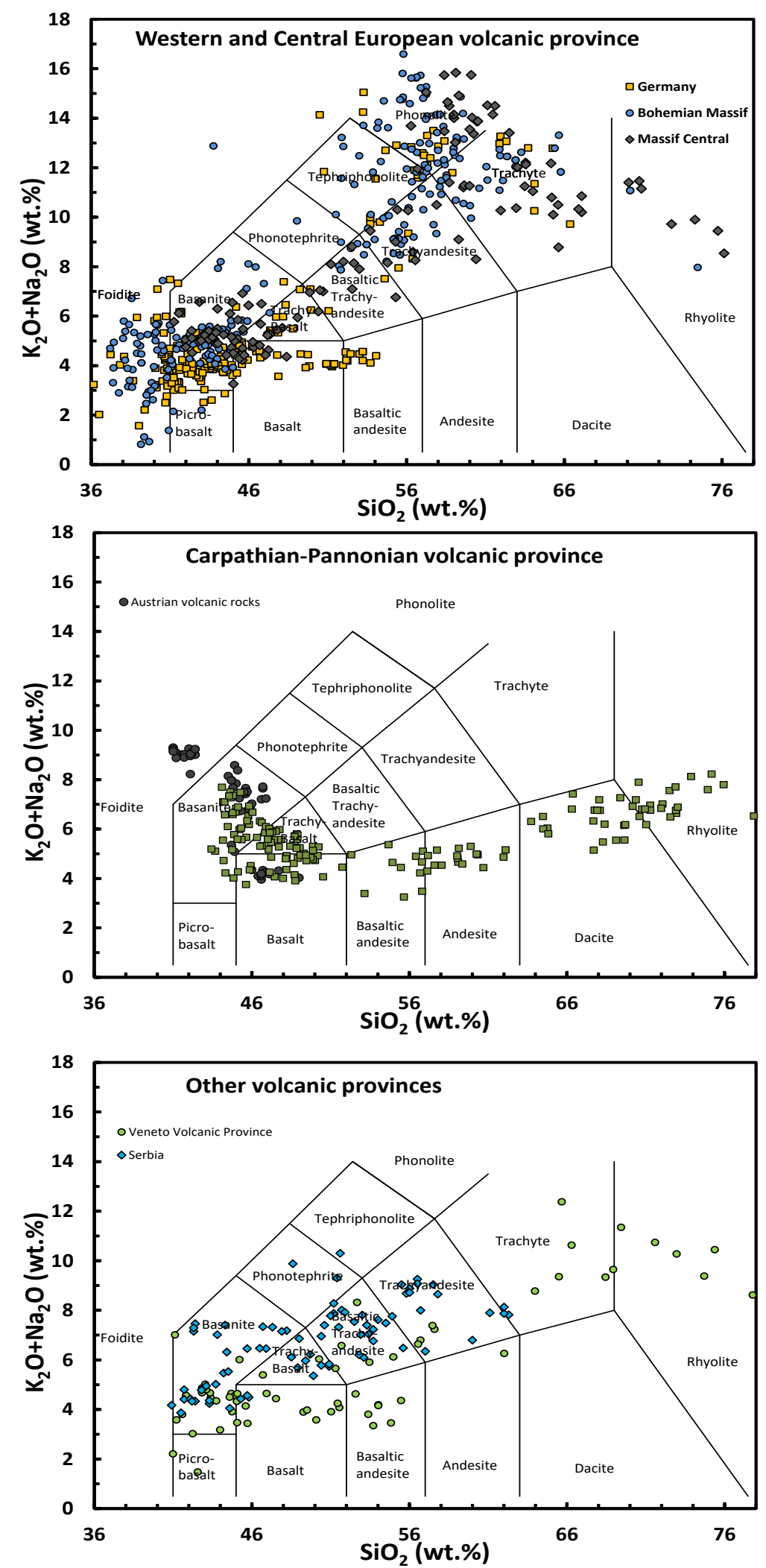

Figure 3: Total alkali content $\left(\mathrm{Na}_{2} \mathrm{O}+\mathrm{Na}_{2} \mathrm{O}\right)$ versus $\mathrm{Si}_{2} \mathrm{O}$ of selected volcanic rocks in the wider vicinity of Austria. (a) Carpathian - Pannonian region; data from (Ali et al., 2013; Ali and Ntaflos, 2011; Harangi et al., 2015, 2007; Lukács et al., 2018), (b) Western and Central European volcanic province (Alibert et al., 1983; Briot et al., 1991; Chauvel and Jahn, 1984; Dautria et al., 2004; Haase et al., 2017, 2004; Hegner et al., 1995; Jung et al., 2006; Jung and Masberg, 1998; Mertes and Schmincke, 1985; Riley et al., 1999; Ulrych et al., 2011, 2003; Wilson et al., 1995; Wörner and Schmincke, 1984); (c) Other volcanic regions (Macera et al., 2003; Milani et al., 1999; Prelević et al., 2005) 


\subsubsection{Agricultural areas in Austria}

Cropland area covered approximately 1,325 M ha in 2019 (Statistik Austria, 2020), and additional 0,576 $M$ ha were categorized as intensive grassland (Statistik Austria, 2018), assumed to be easily available for inorganic fertilizer application. Out of 1152 representative soil samples $38 \%$ have a soil $\mathrm{pH}>7$, in $53 \%$ of samples the $\mathrm{pH}$ ranges from 5-7 and $9 \%$ are characterized as strongly acidic $(\mathrm{pH}=4-5)$. For grass land only $6 \%$ show a pH $>7,55 \%$ of the samples are in the range $5-7$ and $39 \%$ are between $\mathrm{pH} 4$ and pH 5 (Schwarz and Freudenschuss, 2004). Soil amelioration is mostly proposed for acidic soils. However, from a perspective of $\mathrm{CO}_{2}$ sequestration, soil pH has relatively low impact as long as basalt is used for soil amelioration. The dissolution rate of basaltic glass in the relevant range (4-8.5) reaches a minimum around $\mathrm{pH} 6$ (see figure 1). Compared to this minimum, it is $\sim 3$ times faster compared at $\mathrm{pH} 5$ and it is also 3 times faster at $\mathrm{pH} 8$. A pronounced $\mathrm{pH}$ effect would only be expected for very acid conditions - at pH 4 the dissolution rate is $\sim 17$ times that of pH 6 (Gislason and Oelkers, 2003). From this perspective basaltic soil amelioration could also be applied to lime rich alkaline soils which contribute important agricultural areas in Austria, where it could provide a Potassium source, decreasing the need for conventional fertilizers. In summary, an area of 1,902 million ha (cropland plus intensive grassland) are assumed a reasonable maximum area of application and will be used in further modelling exercises.

\subsubsection{Mining, transport and comminution}

The energy demand related to crushing and grinding of material in order to reach particle sizes, small enough to achieve desirable weathering rates in soil are considered and important drawback of EW (Gerdemann et al., 2007; Moosdorf et al., 2014; Renforth et al., 2015; Rigopoulos et al., 2018b). To evaluate the interrelationship between $\mathrm{CO}_{2}$ emissions from comminution and drawdown rate of $\mathrm{CO}_{2}$, three scenarios with different grain size distribution are used for modelling in the range $100-0,1 \mu \mathrm{m}$ $(<100 \mu \mathrm{m}), 10-0,1 \mu \mathrm{m}(<10 \mu \mathrm{m})$ and 1-0,1 $\mu \mathrm{m}(<1 \mu \mathrm{m})$. The particle size distribution was calculated for fixed classes, with normal distribution with a $\mu$ of 50,5 and 0,5 and $\sigma$ of 30,3 and 0.3 , respectively. The resulting grain size distribution can be found in the supplementary file (table S1). Comminution, mining and application can be considered static and resulting input parameters, used for calculation of the $\mathrm{CO}_{2}$ balance are listed in Table 2. Based on the relatively widespread availability of mafic and ultramafic volcanic rocks (see above) the average distance from mine to field was estimated roughly about $300 \mathrm{~km}$. This is an optimistic approach, assuming that the basalt quarries closest to the Austrian border are also able to produce the required amount and quality. Resulting transport related $\mathrm{CO}_{2}$ emissions considered in this study, are $4.8 \mathrm{~kg} \mathrm{CO}_{2 \mathrm{e}} \mathrm{t}^{-1}, 18.9 \mathrm{~kg} \mathrm{CO}_{2 \mathrm{e}} \mathrm{t}^{-1}$ and 59.4 $\mathrm{kg} \mathrm{CO} \mathrm{C}^{-1}$, for transport by rail, a $<7.5 \mathrm{t}$ truck and $20-40 \mathrm{t}$ truck, respectively. Total $\mathrm{CO}_{2 \mathrm{e}}$ emissions including mining, comminution, transport and application calculated on base of $300 \mathrm{~km}$ transport are 
shown in table 3 for three scenarios, using different grain size distributions $(<100 \mu \mathrm{m},<10 \mu \mathrm{m},<1$ $\mu \mathrm{m})$.

\begin{tabular}{|l|c|c|c|c|}
\hline & $\mathrm{kg} \mathrm{CO}_{2} \mathrm{kWh}^{-1}$ & $\mathrm{~kg} \mathrm{CO}_{2} \mathrm{e} \mathrm{t}^{-1} \mathrm{~km}$ & $\mathrm{kWh} \mathrm{t}^{-1}$ & $\mathrm{~kg} \mathrm{CO}_{2} \mathrm{t}^{-1}$ \\
\hline electricity generation (Austria) & 0.26 & & & \\
Road transport $(<7.5 \mathrm{t})^{2}$ & & 0.198 & & \\
Road transport $(20-40 \mathrm{t})^{2}$ & & 0.063 & & \\
Railway transport $^{2}$ & & 0.016 & & \\
comminution $(<100 \mu \mathrm{m})^{3}$ & & & 18.9 & 4.9 \\
comminution $(<10 \mu \mathrm{m})^{4}$ & & & 173.0 & 45.0 \\
comminution $(<1 \mu \mathrm{m})^{5}$ & & & 556.0 & 144.6 \\
Mining $^{5}$ & & & & 7.0 \\
application low estimate $^{5}$ & & & & 1.0 \\
application high estimate $^{5}$ & & & & 4.0 \\
\hline
\end{tabular}

Table 2: Input parameters, used for the calculation of the $\mathrm{CO}_{2}$ balance.

${ }^{1}$ https://secure.umweltbundesamt.at/co2mon/co2mon.html; ${ }^{2}$ (Schmied and Knörr, 2013); ${ }^{3}$ Energy requirement for comminution to $<100 \mu \mathrm{m}$ from the table of bond work index

(https://www.911metallurgist.com/blog/table-of-bond-work-index-by-minerals); ${ }^{4}$ (Hangx and Spiers, 2009); ${ }^{5}$ (Moosdorf et al., 2014)

\begin{tabular}{|c|c|c|c|}
\hline Grain size & Railway transport & Road transport (20-40 t) & Road transport $(<7.5 \mathrm{t})$ \\
\hline$<100 \mu \mathrm{m}$ & 19.1 & 33.2 & 76.7 \\
$<10 \mu \mathrm{m}$ & 56.8 & 71.9 & 115.4 \\
$<1 \mu \mathrm{m}$ & 156.4 & 171.5 & 215.0 \\
\hline
\end{tabular}

Table 3: Total $\mathrm{CO}_{2}$ emissions in $\mathrm{kg} \mathrm{t}^{-1}$ of rock, including mining, transport, comminution and application.

\section{Results and discussion}

\subsection{Influence of particle size on weathering rates}

Based on Eq. 4 the average SSA $A_{\text {BET }}$ resulting is $10.53(<100 \mu \mathrm{m}), 18.61(<10 \mu \mathrm{m})$ and $67.42 \mathrm{~m}^{2} / \mathrm{g}(<1$ $\mu \mathrm{m})$, respectively which is in good agreement with the $\mathrm{SSA}_{\mathrm{BET}}$ of around $10.5 \mathrm{~m}^{2} / \mathrm{g}$, measured by Kelland et al. (2020) in the $<90 \mu \mathrm{m}$ fraction of their basalt powder. Time for complete dissolution of all basalt was calculated to be 1696, 134 and 10.7 years for the $<100 \mu \mathrm{m},<10 \mu \mathrm{m}$ and $<1 \mu \mathrm{m}$ powder, respectively. As the reservoir gets depleted and the grains become increasingly small, dissolution becomes relatively ineffective and for instance $87 \%$ of a $100 \mu \mathrm{m}$ grain will have dissolved in half the time, needed for complete dissolution. Accordingly, the evaluated timeframe in this study 
is for $97.5 \%$ dissolution in which case the dissolution takes 1205, 96 and 7.6 years (Table S1). As this time is based on the largest size grains in each powder, smaller grains will dissolve completely and based on the chosen grain size distribution $>99.9 \%$ of the basalt powder will dissolve within the chosen timeframe already (see figure $\mathrm{S} 1$ in the supplementary file). The potential $\mathrm{CO}_{2}$ drawdown associated with this dissolution is shown in figures $4 a-4 c$ for the first 10 years and $R_{\text {cO2 max }}$ and $R_{\text {cO2 }}$ low.
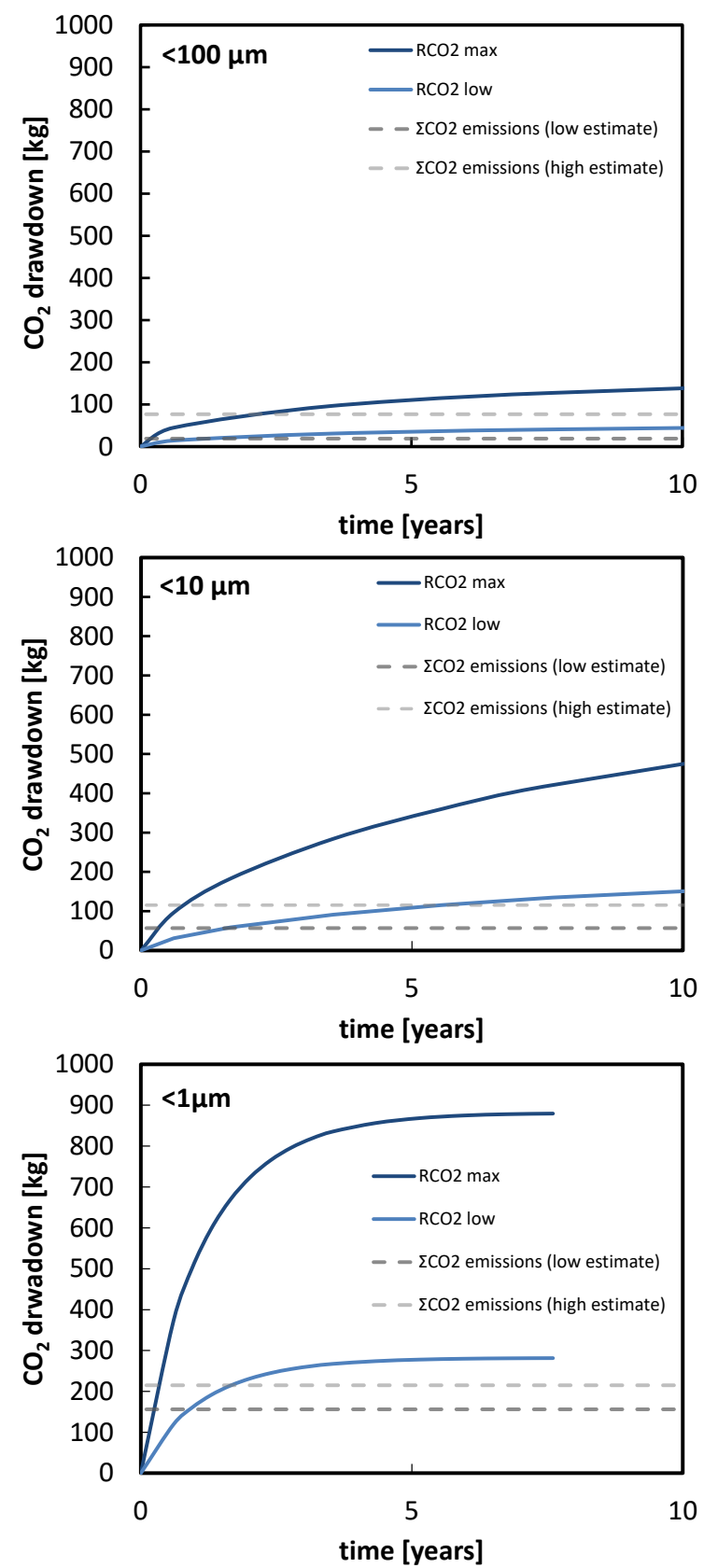

Figure 4: Evolution of $\mathrm{CO}_{2}$ drawdown in $\mathrm{kg} \mathrm{t}^{-1}$ of basalt, using $R_{\mathrm{CO} 2 ~ l o w}$ of $282 \mathrm{~kg}$ and $R_{\mathrm{CO} 2 \max }$ of $880 \mathrm{~kg}$. Grey dashed lines denote the estimates for $\mathrm{CO} 2$ emissions, generated through mining, grinding, transport (300km) and application; the low estimate is based on railway transport; the high estimate is based on road transport using a $<7.5 t$ truck. 
Based on their experiments, Kelland et al. (2020) modelled a cumulative removal of $\mathrm{CO}_{2}$ of $44 \mathrm{~kg} \mathrm{CO}$ $\mathrm{t}^{-1}$ of basalt within 5 years through the application of basalt with a diameter of $<128 \mu \mathrm{m}$. This drawdown was not linear and the largest fraction was drawn down during the 120 days experimental run (30 kg CO $\mathrm{t}^{-1}$ basalt) in good agreement with our calculation for the $<100 \mu \mathrm{m}$ (figure $4 \mathrm{a}$ ).

Within the chosen observation period, increasing the reaction rate through decreasing the grain size

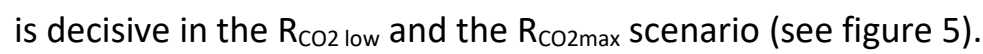
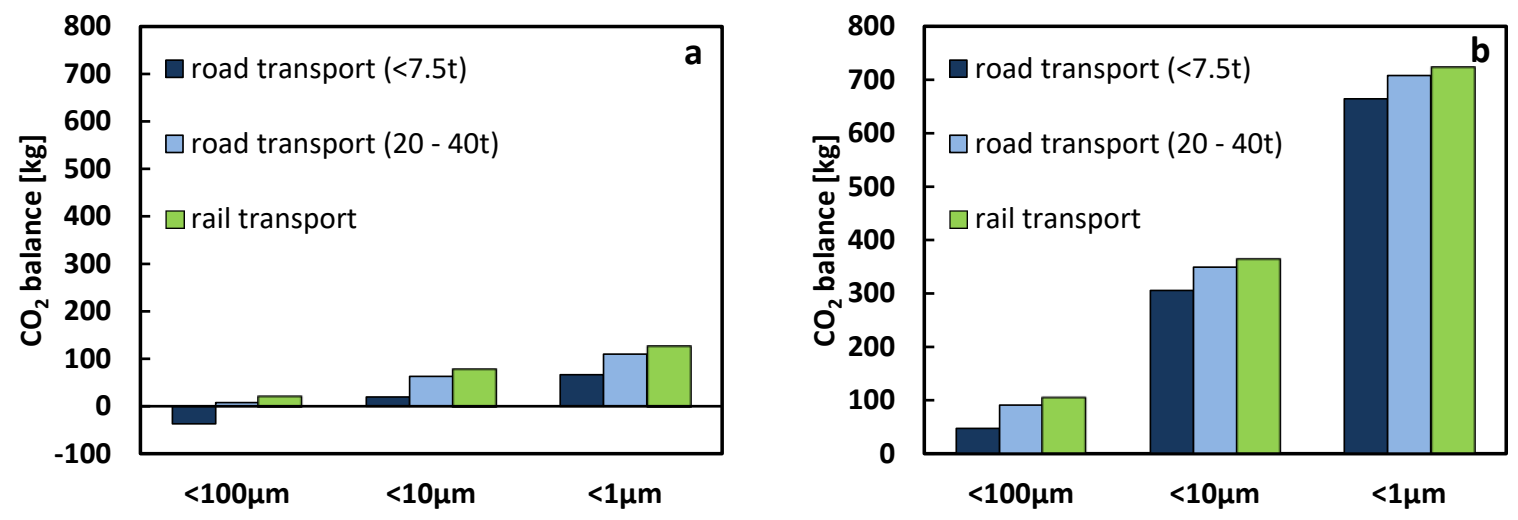

Figure 5: $\mathrm{CO}_{2}$ balance after 7.6 years for different scenarios (see table S2), and $R_{\mathrm{CO} 2 ~ l o w}$ of $282 \mathrm{~kg} \mathrm{CO}_{2} t^{-1}$ rock (a) and $R_{\mathrm{CO} 2 \max }$ of $880 \mathrm{~kg} \mathrm{CO} \mathrm{C}^{-1}$ rock (b).

Apparently comminution, despite its high energy demand is not the controlling factor on the $\mathrm{CO}_{2}$ drawdown. On the contrary, given the slow dissolution of the $<100 \mu \mathrm{m}$ fraction (1698 years for complete dissolution), even best practice (rail transport) will only contribute limited to climate change mitigation (see table S2 and figure 5) and in the case of poor logistics (truck transport $<7.5 \mathrm{t}$ ) it could take $\sim 40$ years until the $\mathrm{CO}_{2}$ balance reaches at least net 0 . However, under a $\mathrm{R}_{\mathrm{cO} 2 \max }$ scenario, considerable $\mathrm{CO}_{2}$ drawdown could be reached even with a relatively large particle size. It can be argued that $R_{\text {cormax }}$ is high and has not been proposed by any of the other studies in context with basalt application. The exact mechanisms of $\mathrm{CO}_{2}$ drawdown during basalt weathering and the corresponding $\mathrm{R}_{\mathrm{CO} 2 \mathrm{max}}$ are still unclear (see above) but in any case the assumed drawdown is close to the drawdown for e.g. olivine, showing the potential within ultramafic rocks in general. We note that grinding down to $<1 \mu \mathrm{m}$ is to our knowledge technically not possible at this moment at industrial scale. Notwithstanding the practical implications of the high energy demand (see section 3.3 ) it goes to show however that the smallest technically possible grain size should be aimed at. The comminution of material to a grainsize in the range of $10 \mu \mathrm{m}$ could be achieved with lower energy input, than assumed in prior publications, given the application of state of the art milling equipment (de Bakker, 2014; Gao et al., 2002). 


\subsection{Cumulative $\mathrm{CO}_{2}$ removal}

Assuming the maximum application on both intensive grassland (0,576 $\mathrm{M}$ ha) and agricultural land $(1,326 \mathrm{M} \mathrm{ha})$, we can estimate the amount of $\mathrm{CO}_{2}$ drawdown potential for the application of $10 \mathrm{~kg}$ $\mathrm{rock} / \mathrm{m}^{2}$ (100t/ha). The cumulative amount of basalt applied in this case is $190 \mathrm{Mt}$. Using rail transport

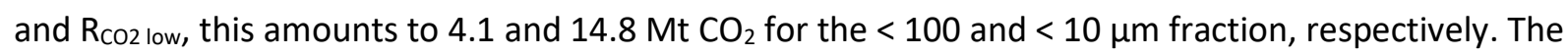
annual output of greenhouse gases in Austria amount to roughly $80 \mathrm{Mt} \mathrm{CO}_{2} \mathrm{e}$ (Klimaschutzreport, 2019).This translates into a net removal of $5.2 \%$ and $18.5 \%$ of Austria's annual greenhouse gas emissions $\left(\mathrm{CO}_{2} \mathrm{e}\right)$ within the observed $\sim 8$ year cycle (see table $\mathrm{S} 2$ ). It is important to note however, that current transportation practices could easily turn this into a positive emission technology (see figure 4a and table S2). For $R_{\text {co2max }}$ the potential drawdown would be tremendous from $25 \%(<100 \mu \mathrm{m}$ ) up to a maximum of $86.6 \%(<10 \mu \mathrm{m})$ of Austria's annual greenhouse gas emissions $\left(\mathrm{CO}_{2} \mathrm{e}\right)$ within a 8 year cycle. This is in good agreement with the study of (Moosdorf et al., 2014), who used a comparable $\mathrm{R}_{\mathrm{cO} 2}$ to evaluate the potential of ultramafic rocks and found that on a global scale transport would not influence $\mathrm{CO}_{2}$ drawdown in way which makes the application unfeasible. We note however that including reaction rates, the net $\mathrm{CO}_{2}$ removal after $\sim 8$ years in our estimate is $105(<100 \mu \mathrm{m})$ and 364 $(<10 \mu \mathrm{m}) \mathrm{kg} \mathrm{CO}_{2} \mathrm{t}^{-1}$. The range of $500-1000 \mathrm{~kg} \mathrm{CO}_{2} \mathrm{t}^{-1}$ obtained for complete dissolution is misleading because it hides the timeframe needed to achieve such drawdown.

\subsection{Associated energy requirement}

The electricity generation in Austria amounted up to 73460 GWh (20901 GWh of that was generated through biogenic or fossil fuels) in the year 2019 (https://www.e-control.at/betriebsstatistik2019) in contrast to $32904 \mathrm{GWh}$ and $3595 \mathrm{GWh}$, needed for grinding down of $190 \mathrm{Mt}$ of basalt to $<10 \mu \mathrm{m}$ and $<100 \mu \mathrm{m}$, respectively. Approximately $45 \%$ or $4.9 \%$ of the annual power generation is required. Given the relatively long time for complete dissolution of the powder, it can be argued, that application would not be carried out every year and the optimal application rate is yet to be determined. Still, even if the application cycle is 10 years the energy requirement is $4.5 \%(<10 \mu \mathrm{m})$ $0.5 \%(<100 \mu \mathrm{m})$ of annual electricity generation. A detailed analysis of the transformation and growth potential of the energy sector in Austria over the next decades is outside the scope of this study. However we note, that back until the year 2001, the amount of electricity import was always greater than export. Reducing energy demand is considered one of the key factors in fighting climate change over the next decades and in this context liberating $0.5 \%$ of the annual electricity generation for rock comminution will not be an easy task. 


\subsection{The amount of basalt needed}

With an assumed density of $3 \mathrm{~g} / \mathrm{cm}^{3}$, the $190 \mathrm{Mt}$ basalt fill a volume of $0.063 \mathrm{~km}^{3}$ (a cube of approximately $400 \mathrm{~m}$ side length). The annual amount of basalt mined in Austria was around 1.5-2 Mt in the years 2015-2018 (Österreichisches Montan-Handbuch 2019 - 93. Jahrgang, 2019). The cumulative amount of all mined rocks and minerals amounts to $70 \mathrm{Mt} /$ year. The necessary amount of basalt can most likely not be sustained through mining on Austrian territory, although large volumes of volcanic rock might be found beneath the surface (Heritsch, 1982). $100 \mathrm{t} \mathrm{ha}^{-1}$ is high and it has been shown that considerable $\mathrm{CO}_{2}$ drawdown can also be achieved with lower application rates (Dietzen et al., 2018; ten Berge et al., 2012), potentially allowing to reduce the amount of basalt. In any case, the mafic lavas of the central European volcanic province in Germany comprise several thousand $\mathrm{km}^{3}$ (Jung et al., 2005) and the eruptive volume of the Vogelsberg (central Germany) alone is $\sim 600 \mathrm{~km}^{3}$ (Bogaard et al., 2003). (Kereszturi et al., 2011) calculated a volume of volcanic rocks for the Bakony-Balaton Highland Volcanic Field in the Pannonian Carpathian region of $\sim 2.9 \mathrm{~km}^{3}$ and large volumes of volcanic rocks are present in the bohemian massif, for instance in the doupov mountains (123 km³) (Shrbený, 1995). The chaine de puys erupted $\sim 10 \mathrm{~km} 3$ of basalt and trachyte (Martel et al., 2013). Conclusively, there is potential for basaltic rock mining in central Europe for several application cycles on agricultural land, not just in Austria. However, mining even if related to sustainable agriculture and climate change mitigation inevitable is in confrontation with other aspect of environmental protection, related to biodiversity, protected areas and economic and societal factors, related to tourism and recreational value. The enormous touristic potential of some of the regions, by means of cultural heritage, the thermal spa tourism often related to Cenozoic volcanism, agricultural use in general and the high quality wines often related to volcanic terrains in particular put limits on mining capacity of the regions. In addition, environmental impact assessment of related mining projects can be enduring. Even if a first assessment shows the enormous volumes of volcanic rocks in Central Europe, not every occurrence will provide the desired chemical composition (see figure 2) and high quality outcrops are already being heavily exploited. Therefore if basalt fertilizer is to play a more prominent role in Austria's (and Europe's) land management practices, strategic planning of the resources use is now warranted on the European level. 


\section{Conclusion}

This study assessed the potential of EW through application of basalt on agricultural area in Austria. Two alternative scenarios for basalt with high $\left(\mathrm{R}_{\mathrm{CO}_{-} \text {max }}=880 \mathrm{~kg} \mathrm{CO}_{2} \mathrm{t}^{-1}\right)$ and low $\left(\mathrm{R}_{\mathrm{cO} 2 \text { low }}=282 \mathrm{~kg} \mathrm{CO}_{2}\right.$ $\left.\mathrm{t}^{-1}\right) \mathrm{CO}_{2}$ drawdown potential were evaluated for a single application and a reaction time of $\sim 8$ years and three different grain sizes $(<100 \mu \mathrm{m},<10 \mu \mathrm{m}$ and $<1 \mu \mathrm{m})$. For a transport distance of $300 \mathrm{~km}$ the net drawdown of $\mathrm{CO}_{2}$ increases with decreasing grain size from $22 \mathrm{~kg} \mathrm{CO}_{2} \mathrm{t}^{-1}$ to $125 \mathrm{~kg} \mathrm{CO}_{2} \mathrm{t}^{-1}$ in the $\mathrm{R}_{\mathrm{CO} \_ \text {low }}$ scenario, if transport is carried out by railway. Our results also indicate, that road transport would turn the application of a $<100 \mu \mathrm{m}$ grain size ineffective or worse, even contribute $\mathrm{CO}_{2}$ emission. However, transport becomes less important with decreasing grain size. Application of of $100 \mathrm{t} \mathrm{ha}^{-1}$ with $\mathrm{a}<10 \mu \mathrm{m}$ grain size could draw down approximately $2 \%$ of Austria's annual greenhouse gas emissions. The huge energy demand related to the grinding of this amount of rock, based on a application cycle of 10 years, would require up to $\sim 5$ of Austria's total annual power generation. Larger grain sizes have been proposed to circumvent this problem, but our results suggest this energy will have to be available, if enhanced basalt weathering is to make an impact on the $\mathrm{CO}_{2}$ budget.

However, at the moment, uncertainties related to effective mechanisms of $\mathrm{CO}_{2}$ consumption during weathering hinder precise quantification. Stoichiometric dissolution of basalt including $\mathrm{Al}^{3+}$, could withdraw higher amounts of $\mathrm{CO}_{2}\left(\mathrm{R}_{\mathrm{CO} 2}\right.$ max $\left.=880 \mathrm{~kg} \mathrm{CO}_{2} \mathrm{t}^{-1}\right)$, in which case the application of larger grain sizes $(<100 \mu \mathrm{m})$ could be sufficient. Uncertainties regarding the actual field weathering rates of basalt powder in soil further complicate our ability to quantify the $\mathrm{CO}_{2}$ drawdown related to $\mathrm{EW}$. The precise determination of these rates remains a crucial requirement towards the large scale application of EW. Further studies from laboratory to field scale under different conditions will be necessary to overcome these deficiencies to put the available resources to optimal use within a European strategy. In addition the influence of agricultural practice on greenhouse gas emissions is increasingly put into focus in the context of climate policy, e.g. the EU LULUCF regulation (Romppanen, 2020), and soil amelioration through the application of basalt could become an integral part of soil carbon management.

At last, the energy demand related to EW produces an obvious conundrum. EW is in conflict with the need to reduce energy consumption and the necessary phasing out of fossil fuel based energy. As such, EW relies on our transformation into a sustainable society with a low carbon economy and abundant low carbon power supply to contribute to climate change mitigation. It does vice versa not contribute to this transformation. 


\section{Acknowledgements}

We thank Sylke Hilberg for insightful discussions during the preparation of this article. Diego BedoyaGonzález and Timo Kessler are thanked for their help with creation of the map. Kayla lacovino is thanked for providing an excel sheet for plotting TAS diagrams on her website (www.kaylaiacovino.com). This research did not receive any specific grant from funding agencies in the public, commercial, or not-for-profit sectors. 


\section{Bibliography}

Adrees, M., Ali, S., Rizwan, M., Zia-ur-Rehman, M., Ibrahim, M., Abbas, F., Farid, M., Qayyum, M.F., Irshad, M.K., 2015. Mechanisms of silicon-mediated alleviation of heavy metal toxicity in plants: A review. Ecotoxicol. Environ. Saf. 119, 186-197.

https://doi.org/https://doi.org/10.1016/j.ecoenv.2015.05.011

Ali, S., Ntaflos, T., 2011. Alkali basalts from Burgenland, Austria: Petrological constraints on the origin of the westernmost magmatism in the Carpathian-Pannonian Region. Lithos 121, 176-188. https://doi.org/10.1016/j.lithos.2010.11.001

Ali, S., Ntaflos, T., Upton, B.G.J., 2013. Petrogenesis and mantle source characteristics of Quaternary alkaline mafic lavas in the western Carpathian-Pannonian Region, Styria, Austria. Chem. Geol. 337-338, 99-113. https://doi.org/10.1016/j.chemgeo.2012.12.001

Alibert, C., Michard, A., Albarède, F., 1983. The transition from alkali basalts to kimberlites: isotope and trace element evidence from melilitites. Contrib. to Mineral. Petrol. 82, 176-186.

Amann, T., Hartmann, J., 2019. Ideas and perspectives: Synergies from co-deployment of negative emission technologies. Biogeosciences 16, 2949-2960.

Amann, T., Hartmann, J., Struyf, E., de Oliveira Garcia, W., Fischer, E.K., Janssens, I.A., Meire, P.M., Schoelynck, J., 2020. Enhanced Weathering and related element fluxes-A cropland mesocosm approach. Biogeosciences 17, 103-119.

Amiotte Suchet, P., Probst, J.-L., Ludwig, W., 2003. Worldwide distribution of continental rock lithology: Implications for the atmospheric/soil $\mathrm{CO}_{2}$ uptake by continental weathering and alkalinity river transport to the oceans. Global Biogeochem. Cycles 17. https://doi.org/10.1029/2002GB001891

Anderson, K., Broderick, J.F., Stoddard, I., 2020. A factor of two: how the mitigation plans of 'climate progressive' nations fall far short of Paris-compliant pathways. Clim. Policy 1-15. https://doi.org/10.1080/14693062.2020.1728209

Anderson, K., Peters, G., 2016. The trouble with negative emissions. INSIGHTS | Perspect. 182. https://doi.org/10.1007/s10484-016-1770-6

Asch, K., 2005. GME 5000: 1 : 5 Million International Geological Map of Europe and Adjacent Areas. 
BGR.

Assima, G.P., Larachi, F., Beaudoin, G., Molson, J., 2012. $\mathrm{CO}_{2}$ Sequestration in Chrysotile Mining Residues - Implication of Watering and Passivation under Environmental Conditions. Ind. Eng. Chem. Res. 51, 8726-8734.

Assima, G.P., Larachi, F., Molson, J., Beaudoin, G., 2014. Comparative study of five Québec ultramafic mining residues for use in direct ambient carbon dioxide mineral sequestration. Chem. Eng. J. $245,56-64$.

Babechuk, M.G., Widdowson, M., Kamber, B.S., 2014. Quantifying chemical weathering intensity and trace element release from two contrasting basalt profiles, Deccan Traps, India. Chem. Geol. $363,56-75$.

Bach, L.T., Gill, S.J., Rickaby, R.E.M., Gore, S., Renforth, P., 2019. $\mathrm{CO}_{2}$ Removal With Enhanced Weathering and Ocean Alkalinity Enhancement: Potential Risks and Co-benefits for Marine Pelagic Ecosystems. Front. Clim. 1, 7. https://doi.org/10.3389/fclim.2019.00007

Beccaluva, L., Di Girolamo, P., Serri, G., 1991. Petrogenesis and tectonic setting of the Roman Volcanic Province, Italy. Lithos 26, 191-221. https://doi.org/https://doi.org/10.1016/00244937(91)90029-K

Beerling, D.J., 2017. Enhanced rock weathering: Biological climate change mitigation with co-benefits for food security? Biol. Lett. https://doi.org/10.1098/rsbl.2017.0149

Beerling, D.J., Kantzas, E.P., Lomas, M.R., Wade, P., Eufrasio, R.M., Renforth, P., Sarkar, B., Andrews, M.G., James, R.H., Pearce, C.R., Mercure, J.F., Pollitt, H., Holden, P.B., Edwards, N.R., Khanna, M., Koh, L., Quegan, S., Pidgeon, N.F., Janssens, I.A., Hansen, J., Banwart, S.A., 2020. Potential for large-scale $\mathrm{CO}_{2}$ removal via enhanced rock weathering with croplands. Nature 583, $242-$ 248. https://doi.org/10.1038/s41586-020-2448-9

Beerling, D.J., Leake, J.R., Long, S.P., Scholes, J.D., Ton, J., Nelson, P.N., Bird, M., Kantzas, E., Taylor, L.L., Sarkar, B., Kelland, M., DeLucia, E., Kantola, I., Müller, C., Rau, G., Hansen, J., 2018. Farming with crops and rocks to address global climate, food and soil security /631/449/706/1143 /704/47 /704/106 perspective. Nat. Plants 4, 138-147. https://doi.org/10.1038/s41477-018$0108-y$

Berner, R.A., Lasaga, A.C., Garrels, R.M., 1983. The carbonate-silicate geochemical cycle and its effect on atmospheric carbon dioxide over the past 100 million years. Am. J. Sci. 283, 641-683. 
Bickmore, B.R., Nagy, K.L., Gray, A.K., Brinkerhoff, A.R., 2006. The effect of Al(OH) $)_{4}$ - on the dissolution rate of quartz. Geochim. Cosmochim. Acta 70, 290-305. https://doi.org/10.1016/J.GCA.2005.09.017

Bogaard, P.J.F., Wo, G., Rnery, È., 2003. Petrogenesis of Basanitic to Tholeiitic Volcanic Rocks from the Miocene Vogelsberg, Central Germany, Journal of Petrology. Oxford Academic.

Brantley, S.L., Mellott, N.P., 2000. Surface area and porosity of primary silicate minerals. Am. Mineral. 85, 1767-1783. https://doi.org/https://doi.org/10.2138/am-2000-11-1220

Briot, D., Cantagrel, J.M., Dupuy, C., Harmon, R.S., 1991. Geochemical evolution in crustal magma reservoirs: Trace-element and $\mathrm{Sr}$ ? $\mathrm{Nd}$ [? $\mathrm{O}$ isotopic variations in two continental intraplate series at Monts Dore, Massif Central, France. Chem. Geol. 89, 281-303.

Chauvel, C., Jahn, B.-M., 1984. Nd-Sr isotope and REE geochemistry of alkali basalts from the Massif Central, France. Geochim. Cosmochim. Acta 48, 93-110.

Chernyshev, I. V, Konečný, V., Lexa, J., Kovalenker, V.A., Jeleň, S., Lebedev, V.A., Goltsman, Y. V, 2013. $\mathrm{K}-\mathrm{Ar}$ and Rb-Sr geochronology and evolution of the Štiavnica stratovolcano (Central Slovakia). Geol. Carpathica 64, 327-360.

Cocker, K.M., Evans, D.E., Hodson, M.J., 1998. The amelioration of aluminium toxicity by silicon in higher plants: Solution chemistry or an in planta mechanism? Physiol. Plant. 104, 608-614. https://doi.org/10.1034/j.1399-3054.1998.1040413.x

Cortesogno, L., Cassinis, G., Dallagiovanna, G., Gaggero, L., Oggiano, G., Ronchi, A., Seno, S., Vanossi, M., 1998. The Variscan post-collisional volcanism in Late Carboniferous-Permian sequences of Ligurian Alps, Southern Alps and Sardinia (Italy): a synthesis. Lithos 45, 305-328. https://doi.org/https://doi.org/10.1016/S0024-4937(98)00037-1

Das, A., Krishnaswami, S., Sarin, M.M., Pande, K., 2005. Chemical weathering in the Krishna Basin and Western Ghats of the Deccan Traps, India: Rates of basalt weathering and their controls. Geochim. Cosmochim. Acta 69, 2067-2084.

Dautria, J.-M., Liotard, J.-M., Briot, D., 2004. Particularités de la contamination crustale des phonolites: exemple du Velay oriental (Massif central). Comptes Rendus Geosci. 336, 971-981.

Daval, D., Calvaruso, C., Guyot, F., Turpault, M.P., 2018. Time-dependent feldspar dissolution rates resulting from surface passivation: Experimental evidence and geochemical implications. Earth Planet. Sci. Lett. 498, 226-236. https://doi.org/10.1016/j.epsl.2018.06.035 
Daval, D., Hellmann, R., Saldi, G.D., Wirth, R., Knauss, K.G., 2013. Linking nm-scale measurements of the anisotropy of silicate surface reactivity to macroscopic dissolution rate laws: New insights based on diopside. Geochim. Cosmochim. Acta 107, 121-134. https://doi.org/10.1016/j.gca.2012.12.045

de Bakker, J., 2014. Energy Use of Fine Grinding in Mineral Processing. Metall. Mater. Trans. E 1, 819. https://doi.org/10.1007/s40553-013-0001-6

Dessert, C., Dupré, B., François, L.M., Schott, J., Gaillardet, J., Chakrapani, G., Bajpai, S., 2001. Erosion of Deccan Traps determined by river geochemistry: impact on the global climate and the ${ }^{87} \mathrm{Sr} /{ }^{86} \mathrm{Sr}$ ratio of seawater. Earth Planet. Sci. Lett. 188, 459-474.

Dessert, C., Dupré, B., Gaillardet, J., François, L.M., Allègre, C.J., 2003. Basalt weathering laws and the impact of basalt weathering on the global carbon cycle. Chem. Geol. 202, 257-273. https://doi.org/10.1016/j.chemgeo.2002.10.001

Dietzen, C., Harrison, R., Michelsen-Correa, S., 2018. Effectiveness of enhanced mineral weathering as a carbon sequestration tool and alternative to agricultural lime: An incubation experiment. Int. J. Greenh. Gas Control 74, 251-258. https://doi.org/https://doi.org/10.1016/j.ijggc.2018.05.007

Downes, H., Seghedi, I., Szakacs, A., Dobosi, G., James, D.E., Vaselli, O., Rigby, I.J., Ingram, G.A., Rex, D., Pecskay, Z., 1995. Petrology and geochemistry of late Tertiary/Quaternary mafic alkaline volcanism in Romania. Lithos 35, 65-81. https://doi.org/https://doi.org/10.1016/00244937(95)91152-Y

Echevarria, G., 2018. Genesis and Behaviour of Ultramafic Soils and Consequences for Nickel Biogeochemistry. Springer, Cham, pp. 135-156. https://doi.org/10.1007/978-3-319-61899-9_8

Elliot Smith, M., Carroll, A.R., Mueller, E.R., 2008. Elevated weathering rates in the Rocky Mountains during the Early Eocene Climatic Optimum. Nat. Geosci. 1, 370-374. https://doi.org/10.1038/ngeo205

Emissions Gap Report 2019, 2019. Nairobi.

Fuss, S., William, F.L., Max, W.C., Jérôme, H., Felix, C., Thorben, A., Tim, B., Wagner de Oliveira, G., Jens, H., Tarun, K., Gunnar, L., Gregory, F.N., Joeri, R., Pete, S., José Luis Vicente, V., Jennifer, W., Maria del Mar Zamora, D., Jan, C.M., 2018. Negative emissions-Part 2: Costs, potentials and side effects. Environ. Res. Lett. 13, 63002. 
Gaillardet, J., Dupré, B., Louvat, P., Allègre, C.J., 1999. Global silicate weathering and CO2 consumption rates deduced from the chemistry of large rivers. Chem. Geol. 159, 3-30. https://doi.org/10.1016/S0009-2541(99)00031-5

Galeczka, I., Wolff-Boenisch, D., Oelkers, E.H., Gislason, S.R., 2014. An experimental study of basaltic glass- $\mathrm{H} 2 \mathrm{O}-\mathrm{CO} 2$ interaction at 22 and $50^{\circ} \mathrm{C}$ : Implications for subsurface storage of $\mathrm{CO}_{2}$. Geochim. Cosmochim. Acta 126, 123-145. https://doi.org/https://doi.org/10.1016/j.gca.2013.10.044

Gao, M., Young, M., Allum, P., 2002. IsaMill fine grinding technology and its industrial applications at Mount Isa Mines, in: 34th Annual Meeting Of The Canadian Mineral Processors.

Gautier, J.-M., Oelkers, E.H., Schott, J., 1994. Experimental study of K-feldspar dissolution rates as a function of chemical affinity at $150^{\circ} \mathrm{C}$ and pH 9. Geochim. Cosmochim. Acta 58, 4549-4560. https://doi.org/10.1016/0016-7037(94)90190-2

Gerdemann, S.J., O'Connor, W.K., Dahlin, D.C., Penner, L.R., Rush, H., 2007. Ex Situ Aqueous Mineral Carbonation. Environ. Sci. Technol. 41, 2587-2593. https://doi.org/10.1021/es0619253

Gerrits, R., Wirth, R., Schreiber, A., Feldmann, I., Knabe, N., Schott, J., Benning, L.G., Gorbushina, A.A., 2020. High-resolution imaging of fungal biofilm-induced olivine weathering. Chem. Geol. 119902. https://doi.org/https://doi.org/10.1016/j.chemgeo.2020.119902

Gillman, G.P., Burkett, D.C., Coventry, R.J., 2002. Amending highly weathered soils with finely ground basalt rock, in: Applied Geochemistry. Pergamon, pp. 987-1001. https://doi.org/10.1016/S0883-2927(02)00078-1

Gislason, S.R., Oelkers, E.H., 2003. Mechanism, rates, and consequences of basaltic glass dissolution: II. An experimental study of the dissolution rates of basaltic glass as a function of $\mathrm{pH}$ and temperature. Geochim. Cosmochim. Acta 67, 3817-3832. https://doi.org/10.1016/s00167037(03)00176-5

Gislason, S.R., Oelkers, E.H., Eiriksdottir, E.S., Kardjilov, M.I., Gisladottir, G., Sigfusson, B., Snorrason, A., Elefsen, S., Hardardottir, J., Torssander, P., Oskarsson, N., 2009. Direct evidence of the feedback between climate and weathering. Earth Planet. Sci. Lett. 277, 213-222. https://doi.org/https://doi.org/10.1016/j.epsl.2008.10.018

Gras, A., Beaudoin, G., Molson, J., Plante, B., 2020. Atmospheric carbon sequestration in ultramafic mining residues and impacts on leachate water chemistry at the Dumont Nickel Project, Quebec, Canada. Chem. Geol. 119661. 
Gudbrandsson, S., Wolff-Boenisch, D., Gislason, S.R., Oelkers, E.H., 2014. Experimental determination of plagioclase dissolution rates as a function of its composition and $\mathrm{pH}$ at $22^{\circ} \mathrm{C}$. Geochim. Cosmochim. Acta 139, 154-172. https://doi.org/https://doi.org/10.1016/j.gca.2014.04.028

Gudbrandsson, S., Wolff-Boenisch, D., Gislason, S.R., Oelkers, E.H., 2011. An experimental study of crystalline basalt dissolution from $2 \leqslant \mathrm{pH} \leqslant 11$ and temperatures from 5 to $75^{\circ} \mathrm{C}$. Geochim. Cosmochim. Acta 75, 5496-5509.

Guntzer, F., Keller, C., Meunier, J.D., 2012. Benefits of plant silicon for crops: A review. Agron. Sustain. Dev. https://doi.org/10.1007/s13593-011-0039-8

Gwenzi, W., 2020. Occurrence, behaviour, and human exposure pathways and health risks of toxic geogenic contaminants in serpentinitic ultramafic geological environments (SUGEs): A medical geology perspective. Sci. Total Environ. 700, 134622. https://doi.org/https://doi.org/10.1016/j.scitotenv.2019.134622

Haase, K.M., Beier, C., Regelous, M., Rapprich, V., Renno, A., 2017. Spatial variability of source composition and petrogenesis in rift and rift flank alkaline lavas from the Eger Rift, Central Europe. Chem. Geol. 455, 304-314. https://doi.org/https://doi.org/10.1016/j.chemgeo.2016.11.003

Haase, K.M., Goldschmidt, B., Garbe-Schönberg, C.-D., 2004. Petrogenesis of Tertiary continental intra-plate lavas from the Westerwald region, Germany. J. Petrol. 45, 883-905.

Hamilton, J.L., Wilson, S.A., Morgan, B., Turvey, C.C., Paterson, D.J., Jowitt, S.M., McCutcheon, J., Southam, G., 2018. Fate of transition metals during passive carbonation of ultramafic mine tailings via air capture with potential for metal resource recovery. Int. J. Greenh. Gas Control 71, 155-167. https://doi.org/https://doi.org/10.1016/j.ijggc.2018.02.008

Hangx, S.J.T., Spiers, C.J., 2009. Coastal spreading of olivine to control atmospheric $\mathrm{CO}_{2}$ concentrations: A critical analysis of viability. Int. J. Greenh. Gas Control 3, 757-767.

Haque, F., Santos, R.M., Chiang, Y.W., 2020a. CO2 sequestration by wollastonite-amended agricultural soils - An Ontario field study. Int. J. Greenh. Gas Control 97, 103017. https://doi.org/10.1016/j.ijggc.2020.103017

Haque, F., Santos, R.M., Chiang, Y.W., 2020b. Optimizing Inorganic Carbon Sequestration and Crop Yield With Wollastonite Soil Amendment in a Microplot Study. Front. Plant Sci. 11, 1012. https://doi.org/10.3389/fpls.2020.01012 
Haque, F., Santos, R.M., Dutta, A., Thimmanagari, M., Chiang, Y.W., 2019. Co-benefits of wollastonite weathering in agriculture: $\mathrm{CO}_{2}$ sequestration and promoted plant growth. ACS omega 4, 14251433.

Harangi, S., Downes, H., Thirlwall, M., Gméling, K., 2007. Geochemistry, Petrogenesis and Geodynamic Relationships of Miocene Calc-alkaline Volcanic Rocks in the Western Carpathian Arc, Eastern Central Europe. J. Petrol. 48, 2261-2287. https://doi.org/10.1093/petrology/egm059

Harangi, S., Jankovics, M.É., Sági, T., Kiss, B., Lukács, R., Soós, I., 2015. Origin and geodynamic relationships of the Late Miocene to Quaternary alkaline basalt volcanism in the Pannonian basin, eastern-central Europe. Int. J. Earth Sci. 104, 2007-2032.

Harrison, A.L., Dipple, G.M., Power, I.M., Mayer, K.U., 2015. Influence of surface passivation and water content on mineral reactions in unsaturated porous media: Implications for brucite carbonation and $\mathrm{CO}_{2}$ sequestration. Geochim. Cosmochim. Acta 148, 477-495. https://doi.org/10.1016/j.gca.2014.10.020

Harrison, A.L., Dipple, G.M., Song, W., Power, I.M., Mayer, K.U., Beinlich, A., Sinton, D., 2017. Changes in mineral reactivity driven by pore fluid mobility in partially wetted porous media. Chem. Geol. 463, 1-11. https://doi.org/10.1016/j.chemgeo.2017.05.003

Harrison, A.L., Power, I.M., Dipple, G.M., 2013. Accelerated carbonation of brucite in mine tailings for carbon sequestration. Environ. Sci. Technol. 47, 126-134. https://doi.org/10.1021/es3012854

Hartmann, J., Moosdorf, N., 2012. The new global lithological map database GLiM: A representation of rock properties at the Earth surface. Geochemistry, Geophys. Geosystems 13.

Hartmann, J., West, A.J., Renforth, P., Köhler, P., De La Rocha, C.L., Wolf-Gladrow, D.A., Dürr, H.H., Scheffran, J., 2013. Enhanced chemical weathering as a geoengineering strategy to reduce atmospheric carbon dioxide, supply nutrients, and mitigate ocean acidification. Rev. Geophys. 51, 113-149. https://doi.org/10.1002/rog.20004

Hegner, E., Walter, H.J., Satir, M., 1995. Pb-Sr-Nd isotopic compositions and trace element geochemistry of megacrysts and melilitites from the Tertiary Urach volcanic field: source composition of small volume melts under SW Germany. Contrib. to Mineral. Petrol. 122, 322335.

Hensel, J. [from old catalog], 1894. Bread from stones., Bread from stones. A. J. Tafel, Philadelphia, Pa.,. https://doi.org/10.5962/bhl.title.42970 
Heritsch, H., 1982. Die Latite aus der Tiefbohrung in Bad Gleichenberg, Steiermark. Mitt. naturwiss. Ver. Steiermark 112, 27-47.

Hickel, J., Kallis, G., 2020. Is Green Growth Possible? New Polit. Econ. 25, 469-486. https://doi.org/10.1080/13563467.2019.1598964

Hilaire, J., Minx, J.C., Callaghan, M.W., Edmonds, J., Luderer, G., Nemet, G.F., Rogelj, J., del Mar Zamora, M., 2019. Negative emissions and international climate goals-learning from and about mitigation scenarios. Clim. Change 157, 189-219. https://doi.org/10.1007/s10584-01902516-4

Hotchkiss, E.R., Hall Jr, R.O., Sponseller, R.A., Butman, D., Klaminder, J., Laudon, H., Rosvall, M., Karlsson, J., 2015. Sources of and processes controlling $\mathrm{CO}_{2}$ emissions change with the size of streams and rivers. Nat. Geosci. 8, 696-699. https://doi.org/10.1038/ngeo2507

Iler, R.., 1973. Effect of adsorbed alumina on the solubility of amorphous silica in water. J. Colloid Interface Sci. 43, 399-408. https://doi.org/10.1016/0021-9797(73)90386-X

Jung, C., Jung, S., Hoffer, E., Berndt, J., 2006. Petrogenesis of Tertiary Mafic Alkaline Magmas in the Hocheifel, Germany. J. Petrol. 47, 1637-1671. https://doi.org/10.1093/petrology/egl023

Jung, S., Masberg, P., 1998. Major- and trace-element systematics and isotope geochemistry of Cenozoic mafic volcanic rocks from the Vogelsberg (central Germany): Constraints on the origin of continental alkaline and tholeiitic basalts and their mantle sources. J. Volcanol. Geotherm. Res. 86, 151-177. https://doi.org/10.1016/S0377-0273(98)00087-0

Jung, S., Pfänder, J.A., Brügmann, G., Stracke, A., 2005. Sources of primitive alkaline volcanic rocks from the Central European Volcanic Province (Rhön, Germany) inferred from $\mathrm{Hf}$, Os and $\mathrm{Pb}$ isotopes. Contrib. to Mineral. Petrol. 150, 546-559.

Kantola, I.B., Masters, M.D., Beerling, D.J., Long, S.P., DeLucia, E.H., 2017. Potential of global croplands and bioenergy crops for climate change mitigation through deployment for enhanced weathering. Biol. Lett. 13, 20160714. https://doi.org/10.1098/rsbl.2016.0714

Kelemen, P.B., McQueen, N., Wilcox, J., Renforth, P., Dipple, G., Vankeuren, A.P., 2020. Engineered carbon mineralization in ultramafic rocks for $\mathrm{CO}_{2}$ removal from air: Review and new insights. Chem. Geol. 550, 119628. https://doi.org/10.1016/j.chemgeo.2020.119628

Kelland, M.E., Wade, P.W., Lewis, A.L., Taylor, L.L., Sarkar, B., Andrews, M.G., Lomas, M.R., Cotton, T.E.A., Kemp, S.J., James, R.H., Pearce, C.R., Hartley, S.E., Hodson, M.E., Leake, J.R., Banwart, 
S.A., Beerling, D.J., 2020. Increased yield and $\mathrm{CO}_{2}$ sequestration potential with the $\mathrm{C} 4$ cereal Sorghum bicolor cultivated in basaltic rock dust-amended agricultural soil. Glob. Chang. Biol. 26, 3658-3676. https://doi.org/10.1111/gcb.15089

Kereszturi, G., Németh, K., Csillag, G., Balogh, K., Kovács, J., 2011. The role of external environmental factors in changing eruption styles of monogenetic volcanoes in a Mio/Pleistocene continental volcanic field in western Hungary. J. Volcanol. Geotherm. Res. 201, 227-240. https://doi.org/https://doi.org/10.1016/j.jvolgeores.2010.08.018

Kierczak, J., Pedziwiatr, A., Waroszewski, J., Modelska, M., 2016. Mobility of Ni, Cr and Co in serpentine soils derived on various ultrabasic bedrocks under temperate climate. Geoderma 268, 78-91. https://doi.org/10.1016/j.geoderma.2016.01.025

Köhler, P., Hartmann, J., Wolf-Gladrow, D.A., 2010. Geoengineering potential of artificially enhanced silicate weathering of olivine. Proc. Natl. Acad. Sci. U. S. A. 107, 20228-20233. https://doi.org/10.1073/pnas.1000545107

Kump, L.R., Arthur, M.A., Patzkowsky, M.E., Gibbs, M.T., Pinkus, D.S., Sheehan, P.M., 1999. A weathering hypothesis for glaciation at high atmospheric $\mathrm{pCO} 2$ during the Late Ordovician. Palaeogeogr. Palaeoclimatol. Palaeoecol. 152, 173-187. https://doi.org/https://doi.org/10.1016/S0031-0182(99)00046-2

Lackner, K.S., Wendt, C.H., Butt, D.P., Joyce, E.L., Sharp, D.H., 1995. Carbon dioxide disposal in carbonate minerals. Energy 20, 1153-1170. https://doi.org/https://doi.org/10.1016/03605442(95)00071-N

Lechat, K., Lemieux, J.-M., Molson, J., Beaudoin, G., Hébert, R., 2016. Field evidence of $\mathrm{CO}_{2}$ sequestration by mineral carbonation in ultramafic milling wastes, Thetford Mines, Canada. Int. J. Greenh. Gas Control 47, 110-121. https://doi.org/https://doi.org/10.1016/j.ijggc.2016.01.036

Lefebvre, D., Goglio, P., Williams, A., Manning, D.A.C., de Azevedo, A.C., Bergmann, M., Meersmans, J., Smith, P., 2019. Assessing the potential of soil carbonation and enhanced weathering through Life Cycle Assessment: A case study for Sao Paulo State, Brazil. J. Clean. Prod. 233, 468481. https://doi.org/10.1016/j.jclepro.2019.06.099

Li, Gaojun, Hartmann, J., Derry, L.A., West, A.J., You, C.-F., Long, X., Zhan, T., Li, L., Li, Gen, Qiu, W., Li, T., Liu, L., Chen, Y., Ji, J., Zhao, L., Chen, J., 2016. Temperature dependence of basalt weathering. Earth Planet. Sci. Lett. 443, 59-69. https://doi.org/https://doi.org/10.1016/j.epsl.2016.03.015

Liang, Y.C., Ma, T.S., Li, F.J., Feng, Y.J., 1994. Silicon availability and response of rice and wheat to 
silicon in calcareous soils. Commun. Soil Sci. Plant Anal. 25, 2285-2297.

Louvat, P., Allègre, C.J., 1997. Present denudation rates on the island of Reunion determined by river geochemistry: basalt weathering and mass budget between chemical and mechanical erosions. Geochim. Cosmochim. Acta 61, 3645-3669.

Lowe, D.R., Tice, M.M., 2004. Geologic evidence for Archean atmospheric and climatic evolution: Fluctuating levels of $\mathrm{CO}_{2}, \mathrm{CH}_{4}$, and $\mathrm{O}_{2}$ with an overriding tectonic control. Geology 32, 493-496. https://doi.org/10.1130/G20342.1

Lukács, R., Harangi, S., Guillong, M., Bachmann, O., Fodor, L., Buret, Y., Dunkl, I., Sliwinski, J., von Quadt, A., Peytcheva, I., Zimmerer, M., 2018. Early to Mid-Miocene syn-extensional massive silicic volcanism in the Pannonian Basin (East-Central Europe): Eruption chronology, correlation potential and geodynamic implications. Earth-Science Rev. 179, 1-19. https://doi.org/https://doi.org/10.1016/j.earscirev.2018.02.005

Lustrino, M., Wilson, M., 2007. The circum-Mediterranean anorogenic Cenozoic igneous province. Earth-Science Rev. 81, 1-65. https://doi.org/https://doi.org/10.1016/j.earscirev.2006.09.002

Macera, P., Gasperini, D., Piromallo, C., Blichert-Toft, J., Bosch, D., Del Moro, A., Martin, S., 2003. Geodynamic implications of deep mantle upwelling in the source of Tertiary volcanics from the Veneto region (South-Eastern Alps). J. Geodyn. 36, 563-590.

Maher, K., 2010. The dependence of chemical weathering rates on fluid residence time. Earth Planet. Sci. Lett. 294, 101-110. https://doi.org/10.1016/j.epsl.2010.03.010

Maher, K., Steefel, C.I., White, A.F., Stonestrom, D.A., 2009. The role of reaction affinity and secondary minerals in regulating chemical weathering rates at the Santa Cruz Soil Chronosequence, California. Geochim. Cosmochim. Acta 73, 2804-2831. https://doi.org/https://doi.org/10.1016/j.gca.2009.01.030

Martel, C., Champallier, R., Prouteau, G., Pichavant, M., Arbaret, L., Balcone-Boissard, H., Boudon, G., Boivin, P., Bourdier, J.-L., Scaillet, B., 2013. Trachyte Phase Relations and Implication for Magma Storage Conditions in the Chaîne des Puys (French Massif Central). J. Petrol. 54, 1071-1107. https://doi.org/10.1093/petrology/egt006

Marx, A., Dusek, J., Jankovec, J., Sanda, M., Vogel, T., van Geldern, R., Hartmann, J., Barth, J.A.C., 2017. A review of $\mathrm{CO}_{2}$ and associated carbon dynamics in headwater streams: A global perspective. Rev. Geophys. 55, 560-585. https://doi.org/https://doi.org/10.1002/2016RG000547 
Mertes, H., Schmincke, H.-U., 1985. Mafic potassic lavas of the Quaternary West Eifel volcanic field. Contrib. to Mineral. Petrol. 89, 330-345.

Milani, L., Beccaluva, L., Coltorti, M., 1999. Petrogenesis and evolution of the Euganean Magmatic Complex, Veneto region, north-east Italy. Eur. J. Mineral. 11, 379-399.

Montserrat, F., Renforth, P., Hartmann, J., Leermakers, M., Knops, P., Meysman, F.J.R., 2017. Olivine dissolution in seawater: implications for $\mathrm{CO}_{2}$ sequestration through enhanced weathering in coastal environments. Environ. Sci. Technol. 51, 3960-3972.

Moosdorf, N., Renforth, P., Hartmann, J., 2014. Carbon dioxide efficiency of terrestrial enhanced weathering. Environ. Sci. Technol. 48, 4809-4816. https://doi.org/10.1021/es4052022

Navarre-Sitchler, A., Brantley, S., 2007. Basalt weathering across scales. Earth Planet. Sci. Lett. 261, 321-334.

Navarre-Sitchler, A., Steefel, C.I., Sak, P.B., Brantley, S.L., 2011. A reactive-transport model for weathering rind formation on basalt. Geochim. Cosmochim. Acta 75, 7644-7667. https://doi.org/https://doi.org/10.1016/j.gca.2011.09.033

Negative Emissions Technologies and Reliable Sequestration: A Research Agenda, 2019. , Negative Emissions Technologies and Reliable Sequestration. National Academies Press. https://doi.org/10.17226/25259

Oelkers, E.H., Declercq, J., Saldi, G.D., Gislason, S.R., Schott, J., 2018. Olivine dissolution rates: A critical review. Chem. Geol. 500, 1-19. https://doi.org/10.1016/j.chemgeo.2018.10.008

Oelkers, E.H., Gislason, S.R., 2001. The mechanism, rates and consequences of basaltic glass dissolution: I. An experimental study of the dissolution rates of basaltic glass as a function of aqueous $\mathrm{Al}, \mathrm{Si}$ and oxalic acid concentration at $25^{\circ} \mathrm{C}$ and $\mathrm{pH}=3$ and 11 . Geochim. Cosmochim. Acta 65, 3671-3681. https://doi.org/10.1016/\$0016-7037(01)00664-0

Oelkers, E.H., Schott, J., 2001. An experimental study of enstatite dissolution rates as a function of $\mathrm{pH}$, temperature, and aqueous $\mathrm{Mg}$ and Si concentration, and the mechanism of pyroxene/pyroxenoid dissolution. Geochim. Cosmochim. Acta 65, 1219-1231.

Oskierski, H.C., Dlugogorski, B.Z., Oliver, T.K., Jacobsen, G., 2016. Chemical and isotopic signatures of waters associated with the carbonation of ultramafic mine tailings, Woodsreef Asbestos Mine, Australia. Chem. Geol. 436, 11-23.

Österreichisches Montan-Handbuch 2019 - 93. Jahrgang, 2019. 
Peccerillo, A., 2005. Plio-quaternary volcanism in Italy. Springer.

Perez-Fodich, A., Derry, L.A., 2019. Organic acids and high soil CO 2 drive intense chemical weathering of Hawaiian basalts: Insights from reactive transport models. Geochim. Cosmochim. Acta 249, 173-198. https://doi.org/10.1016/j.gca.2019.01.027

Perez, A., Rossano, S., Trcera, N., Verney-Carron, A., Huguenot, D., van Hullebusch, E.D., Catillon, G., Razafitianamaharavo, A., Guyot, F., 2015. Impact of iron chelators on short-term dissolution of basaltic glass. Geochim. Cosmochim. Acta 162, 83-98. https://doi.org/https://doi.org/10.1016/j.gca.2015.04.025

Plata, L.G., Ramos, C.G., Silva Oliveira, M.L., Silva Oliveira, L.F., 2021. Release kinetics of multinutrients from volcanic rock mining by-products: Evidences for their use as a soil remineralizer. J. Clean. Prod. 279, 123668. https://doi.org/10.1016/j.jclepro.2020.123668

Pokrovsky, O.S., Schott, J., 2000. Kinetics and mechanism of forsterite dissolution at $25{ }^{\circ} \mathrm{C}$ and $\mathrm{pH}$ from 1 to 12. Geochim. Cosmochim. Acta 64, 3313-3325.

Polsenaere, P., Savoye, N., Etcheber, H., Canton, M., Poirier, D., Bouillon, S., Abril, G., 2013. Export and degassing of terrestrial carbon through watercourses draining a temperate podzolized catchment. Aquat. Sci. 75, 299-319.

Power, I.M., Dipple, G.M., Bradshaw, P.M.D., Harrison, A.L., 2020. Prospects for $\mathrm{CO}_{2}$ mineralization and enhanced weathering of ultramafic mine tailings from the Baptiste nickel deposit in British Columbia, Canada. Int. J. Greenh. Gas Control 94, 102895.

Prelević, D., Foley, S.F., Romer, R.L., Cvetković, V., Downes, H., 2005. Tertiary Ultrapotassic Volcanism in Serbia: Constraints on Petrogenesis and Mantle Source Characteristics. J. Petrol. 46, 14431487. https://doi.org/10.1093/petrology/egi022

Pronost, J., Beaudoin, G., Tremblay, J., Larachi, F., Duchesne, J., Hébert, R., Constantin, M., 2011. Carbon sequestration kinetic and storage capacity of ultramafic mining waste. Environ. Sci. Technol. 45, 9413-9420.

Raymo, M.E., Ruddiman, W.F., 1992. Tectonic forcing of late Cenozoic climate. Nature 359, 117-122. https://doi.org/10.1038/359117a0

Renforth, P., 2012. The potential of enhanced weathering in the UK. Int. J. Greenh. Gas Control 10, 229-243. https://doi.org/10.1016/j.ijggc.2012.06.011

Renforth, P., Henderson, G., 2017. Assessing ocean alkalinity for carbon sequestration. Rev. Geophys. 
55, 636-674. https://doi.org/10.1002/2016RG000533

Renforth, P., Pogge von Strandmann, P.A.E., Henderson, G.M., 2015. The dissolution of olivine added to soil: Implications for enhanced weathering. Appl. Geochemistry 61, 109-118. https://doi.org/10.1016/j.apgeochem.2015.05.016

Rigopoulos, I., Harrison, A.L., Delimitis, A., Ioannou, I., Efstathiou, A.M., Kyratsi, T., Oelkers, E.H., 2018a. Carbon sequestration via enhanced weathering of peridotites and basalts in seawater. Appl. Geochemistry 91, 197-207. https://doi.org/10.1016/j.apgeochem.2017.11.001

Rigopoulos, I., Török, Á., Kyratsi, T., Delimitis, A., loannou, I., 2018b. Sustainable exploitation of mafic rock quarry waste for carbon sequestration following ball milling. Resour. Policy 59, 24-32. https://doi.org/https://doi.org/10.1016/j.resourpol.2018.08.002

Riley, T.R., Bailey, D.K., Harmer, R.E., Liebsch, H., Lloyd, F.E., Palmer, M.R., 1999. Isotopic and geochemical investigation of a carbonatite-syenite-phonolite diatreme, West Eifel (Germany). Mineral. Mag. 63, 615-631.

Romppanen, S., 2020. The LULUCF Regulation: the new role of land and forests in the EU climate and policy framework. J. Energy Nat. Resour. Law 38, 261-287. https://doi.org/10.1080/02646811.2020.1756622

Savant, N.K., Datnoff, L.E., Snyder, G.H., 1997. Depletion of plant-available silicon in soils: A possible cause of declining rice yields. Commun. Soil Sci. Plant Anal. 28, 1245-1252.

Schlesinger, W.H., Amundson, R., 2019. Managing for soil carbon sequestration: Let's get realistic. Glob. Chang. Biol. 25, 386-389. https://doi.org/10.1111/gcb.14478

Schmied, M., Knörr, W., 2013. Berechnung von Treibhausgasemissionen in Spedition und Logistik gemäß DIN EN 16258. Bonn.

Schuiling, R.D., Krijgsman, P., 2006. Enhanced weathering: An effective and cheap tool to sequester $\mathrm{CO}_{2}$. Clim. Change 74, 349-354. https://doi.org/10.1007/s10584-005-3485-y

Schwarz, S., Freudenschuss, A., 2004. Referenzwerte für Schwermetalle in Oberböden.

Seghedi, I., Downes, H., Vaselli, O., Szakács, A., Balogh, K., Pécskay, Z., 2004. Post-collisional TertiaryQuaternary mafic alkalic magmatism in the Carpathian-Pannonian region: a review. Tectonophysics 393, 43-62. https://doi.org/https://doi.org/10.1016/j.tecto.2004.07.051

Seifritz, W., 1990. $\mathrm{CO}_{2}$ disposal by means of silicates [12]. Nature. https://doi.org/10.1038/345486b0 
Shamshuddin, J., Kapok, J.R., 2010. Effect of Ground Basalt on chemical Properties of an ultisol and oxisol in Malaysia. Pertanika J. Trop. Agric. Sci. 33, 7-14.

Shrbený, O., 1995. Chemical composition of young volcanites of the Czech Republic. Czech Geological Survey Special Paper, 4. Czech Geol. Surv.

Smith, P., Davis, S.J., Creutzig, F., Fuss, S., Minx, J., Gabrielle, B., Kato, E., Jackson, R.B., Cowie, A., Kriegler, E., van Vuuren, D.P., Rogelj, J., Ciais, P., Milne, J., Canadell, J.G., McCollum, D., Peters, G., Andrew, R., Krey, V., Shrestha, G., Friedlingstein, P., Gasser, T., Grübler, A., Heidug, W.K., Jonas, M., Jones, C.D., Kraxner, F., Littleton, E., Lowe, J., Moreira, J.R., Nakicenovic, N., Obersteiner, M., Patwardhan, A., Rogner, M., Rubin, E., Sharifi, A., Torvanger, A., Yamagata, Y., Edmonds, J., Yongsung, C., 2016. Biophysical and economic limits to negative $\mathrm{CO}_{2}$ emissions. Nat. Clim. Chang. 6, 42-50. https://doi.org/10.1038/nclimate2870

Snæbjörnsdóttir, S.Ó., Sigfússon, B., Marieni, C., Goldberg, D., Gislason, S.R., Oelkers, E.H., 2020. Carbon dioxide storage through mineral carbonation. Nat. Rev. Earth Environ. 1, 90-102. https://doi.org/10.1038/s43017-019-0011-8

Statistik Austria, 2020. Anbau auf dem Ackerland; IVEKOS.

Statistik Austria, 2018. Agrarstrukturerhebung 2016.

Steefel, C.I., Van Cappellen, P., 1990. A new kinetic approach to modeling water-rock interaction: The role of nucleation, precursors, and Ostwald ripening. Geochim. Cosmochim. Acta 54, 26572677. https://doi.org/https://doi.org/10.1016/0016-7037(90)90003-4

Stockmann, G.J., Wolff-Boenisch, D., Gislason, S.R., Oelkers, E.H., 2011. Do carbonate precipitates affect dissolution kinetics? 1: Basaltic glass. Chem. Geol. 284, 306-316. https://doi.org/10.1016/j.chemgeo.2011.03.010

Strefler, J., Amann, T., Bauer, N., Kriegler, E., Hartmann, J., 2018. Potential and costs of carbon dioxide removal by enhanced weathering of rocks. Environ. Res. Lett. 13, 34010. https://doi.org/10.1088/1748-9326/aaa9c4

Taylor, L.L., Beerling, D.J., Quegan, S., Banwart, S.A., 2017. Simulating carbon capture by enhanced weathering with croplands: an overview of key processes highlighting areas of future model development. Biol. Lett. 13, 20160868. https://doi.org/10.1098/rsbl.2016.0868

Taylor, L.L., Quirk, J., Thorley, R.M.S., Kharecha, P.A., Hansen, J., Ridgwell, A., Lomas, M.R., Banwart, S.A., Beerling, D.J., 2016. Enhanced weathering strategies for stabilizing climate and averting 
ocean acidification. Nat. Clim. Chang. 6, 402-406. https://doi.org/10.1038/nclimate2882

ten Berge, H.F.M., van der Meer, H.G., Steenhuizen, J.W., Goedhart, P.W., Knops, P., Verhagen, J., 2012. Olivine Weathering in Soil, and Its Effects on Growth and Nutrient Uptake in Ryegrass (Lolium perenne L.): A Pot Experiment. PLoS One 7, e42098.

https://doi.org/10.1371/journal.pone.0042098

Tester, J.W., Worley, W.G., Robinson, B.A., Grigsby, C.O., Feerer, J.L., 1994. Correlating quartz dissolution kinetics in pure water from 25 to $625^{\circ} \mathrm{C}$. Geochim. Cosmochim. Acta 58, 2407-2420. https://doi.org/10.1016/0016-7037(94)90020-5

Thom, J.G.M., Dipple, G.M., Power, I.M., Harrison, A.L., 2013. Chrysotile dissolution rates: Implications for carbon sequestration. Appl. Geochemistry 35, 244-254. https://doi.org/10.1016/j.apgeochem.2013.04.016

Tole, M.P., Lasaga, A.C., Pantano, C., White, W.B., 1986. The kinetics of dissolution of nepheline (NaAlSiO4). Geochim. Cosmochim. Acta 50, 379-392. https://doi.org/https://doi.org/10.1016/0016-7037(86)90191-2

Ulrych, J., Dostal, J., Adamovič, J., Jelínek, E., Špaček, P., Hegner, E., Balogh, K., 2011. Recurrent Cenozoic volcanic activity in the Bohemian Massif (Czech Republic). Lithos 123, 133-144.

Ulrych, J., Lloyd, F.E., Balogh, K., 2003. Age relations and geochemical constraints of Cenozoic alkaline volcanic series in W Bohemia: a review. Geolines 15, 168-180.

Van Straaten, P., 2006. Farming with rocks and minerals: Challenges and opportunities. An. Acad. Bras. Cienc. 78, 731-747. https://doi.org/10.1590/\$0001-37652006000400009

Velbel, M.A., 2009. Dissolution of olivine during natural weathering. Geochim. Cosmochim. Acta 73, 6098-6113. https://doi.org/10.1016/j.gca.2009.07.024

Velbel, M.A., 1993. Constancy of silicate-mineral weathering-rate ratios between natural and experimental weathering: implications for hydrologic control of differences in absolute rates. Chem. Geol. 105, 89-99. https://doi.org/10.1016/0009-2541(93)90120-8

Walker, J.C.G., Hays, P.B., Kasting, J.F., 1981. A negative feedback mechanism for the long-term stabilization of Earth's surface temperature. J. Geophys. Res. Ocean. 86, 9776-9782. https://doi.org/10.1029/JC086iC10p09776

White, A.F., Brantley, S.L., 2003. The effect of time on the weathering of silicate minerals: Why do weathering rates differ in the laboratory and field? Chem. Geol. 202, 479-506. 
https://doi.org/10.1016/j.chemgeo.2003.03.001

Wild, B., Daval, D., Beaulieu, E., Pierret, M.C., Viville, D., Imfeld, G., 2019. In-situ dissolution rates of silicate minerals and associated bacterial communities in the critical zone (Strengbach catchment, France). Geochim. Cosmochim. Acta 249, 95-120. https://doi.org/10.1016/j.gca.2019.01.003

Wilson, M., Downes, H., Cebria, J.-M., 1995. Contrasting fractionation trends in coexisting continental alkaline magma series; Cantal, Massif Central, France. J. Petrol. 36, 1729-1753.

Wilson, S.A., Harrison, A.L., Dipple, G.M., Power, I.M., Barker, S.L.L., Mayer, K.U., Fallon, S.J., Raudsepp, M., Southam, G., 2014. Offsetting of CO2 emissions by air capture in mine tailings at the Mount Keith Nickel Mine, Western Australia: Rates, controls and prospects for carbon neutral mining. Int. J. Greenh. Gas Control 25, 121-140.

Wolff-Boenisch, D., Gislason, S.R., Oelkers, E.H., 2006. The effect of crystallinity on dissolution rates and $\mathrm{CO}_{2}$ consumption capacity of silicates. Geochim. Cosmochim. Acta 70, 858-870. https://doi.org/10.1016/j.gca.2005.10.016

Wolff-Boenisch, D., Gislason, S.R., Oelkers, E.H., Putnis, C. V., 2004. The dissolution rates of natural glasses as a function of their composition at $\mathrm{pH} 4$ and 10.6, and temperatures from 25 to $74^{\circ} \mathrm{C}$. Geochim. Cosmochim. Acta 68, 4843-4858. https://doi.org/10.1016/j.gca.2004.05.027

Workman, M., Dooley, K., Lomax, G., Maltby, J., Darch, G., 2020. Decision making in contexts of deep uncertainty - An alternative approach for long-term climate policy. Environ. Sci. Policy 103, 7784. https://doi.org/10.1016/j.envsci.2019.10.002

Wörner, G., Schmincke, H.-U., 1984. Mineralogical and chemical zonation of the Laacher See tephra sequence (East Eifel, W. Germany). J. Petrol. 25, 805-835. 


\section{Supplementary file}

Table S1: Model parameters of the $<100 \mu \mathrm{m},<10 \mu \mathrm{m}$ and $<1 \mu \mathrm{m}$ fraction. $\%$ denotes the relative fraction of the grain size; Moles denotes the moles of basalt in each grain size; $\mathrm{SSA}_{\mathrm{BET}}$ is calculated after Brantley and Mellott, (2000) (see text below) SSAgeo is calculated after Tester et al., (1994); $r_{\text {geo }}$ is the dissolution rate normalized to geometric surface area; time at which $97.5 \%$ of the respective grain size have dissolved, according to the shrinking core model. Total amount dissolved in moles and $\mathrm{kg} ; R_{\mathrm{CO} 2 \max }$ is the amount of $\mathrm{CO}_{2}$ drawn from the atmosphere calculated from stoichiometric basalt dissolution (see equation 3 in manuscript), $R_{c o z}$ low is calculated based on charge balance for $\mathrm{Ca}^{2+}$ and $\mathrm{Mg}^{2+}$ only.

\begin{tabular}{|c|c|c|c|c|c|c|c|c|c|c|}
\hline $\begin{array}{c}\text { grain } \\
\text { size } \\
{[\mu \mathrm{m}]}\end{array}$ & $\%$ & moles & $\begin{array}{l}\mathrm{SSA}_{\mathrm{BET}} \\
{\left[\mathrm{m}^{2} / \mathrm{g}\right]}\end{array}$ & $\begin{array}{l}\mathrm{SSA}_{\text {geo }} \\
{\left[\mathrm{m}^{2} / \mathrm{g}\right]}\end{array}$ & $\begin{array}{c}r_{\text {geo }} \\
{\left[\mathrm{mol} / \mathrm{m}^{2} / \mathrm{s}\right]}\end{array}$ & $\begin{array}{c}\text { Time } \\
(t) \\
\text { [years] }\end{array}$ & $\begin{array}{c}\text { Amount } \\
\text { dissolved/(t) } \\
\text { [mol] }\end{array}$ & $\begin{array}{c}\text { Amount } \\
\text { dissolved/(t) } \\
{[\mathrm{kg}]}\end{array}$ & $\mathbf{R}_{\mathrm{CO} 2 \text { max }}$ & $\mathbf{R}_{\mathrm{CO} 2 \text { low }}$ \\
\hline 0.1 & 3.2 & 254.8 & 251.2 & 20.0 & $4.5 \mathrm{E}-11$ & 0.6 & 406 & 51 & 45 & 14 \\
\hline 0.5 & 3.3 & 260.5 & 42.8 & 4.0 & $3.8 \mathrm{E}-11$ & 3.5 & 473 & 59 & 97 & 31 \\
\hline 1 & 3.3 & 267.7 & 20.0 & 2.0 & 3.5E-11 & 7.6 & 279 & 35 & 127 & 41 \\
\hline 5 & 4.1 & 329.9 & 3.4 & 0.4 & 3.0E-11 & 44.7 & 1387 & 173 & 280 & 90 \\
\hline 10 & 5.2 & 417.7 & 1.6 & 0.2 & $2.8 \mathrm{E}-11$ & 95.7 & 1207 & 151 & 413 & 132 \\
\hline 20 & 7.7 & 616.3 & 0.7 & 0.1 & $2.6 \mathrm{E}-11$ & 205.2 & 1658 & 207 & 595 & 190 \\
\hline 30 & 10.2 & 813.6 & 0.5 & 0.067 & $2.5 \mathrm{E}-11$ & 320.5 & 1041 & 130 & 710 & 227 \\
\hline 40 & 12.0 & 961.2 & 0.3 & 0.050 & $2.4 \mathrm{E}-11$ & 439.8 & 648 & 81 & 781 & 250 \\
\hline 50 & 12.7 & 1016.1 & 0.3 & 0.040 & $2.4 \mathrm{E}-11$ & 562.2 & 396 & 50 & 824 & 264 \\
\hline 60 & 12.0 & 961.2 & 0.2 & 0.033 & $2.4 \mathrm{E}-11$ & 687.1 & 236 & 29 & 850 & 272 \\
\hline 70 & 10.2 & 813.6 & 0.2 & 0.029 & 2.3E-11 & 814.0 & 135 & 17 & 865 & 277 \\
\hline 80 & 7.7 & 616.3 & 0.2 & 0.025 & $2.3 \mathrm{E}-11$ & 942.8 & 74 & 9 & 873 & 279 \\
\hline 90 & 5.2 & 417.7 & 0.1 & 0.022 & $2.3 \mathrm{E}-11$ & 1073.3 & 37 & 5 & 877 & 281 \\
\hline 100 & 3.2 & 253.4 & 0.1 & 0.020 & $2.2 \mathrm{E}-11$ & 1205.1 & 17 & 2 & 879 & 281 \\
\hline
\end{tabular}

\begin{tabular}{|c|c|c|c|c|c|c|c|c|c|c|}
\hline $\begin{array}{c}\text { grain } \\
\text { size } \\
{[\mu \mathrm{m}]}\end{array}$ & $\%$ & moles & $\begin{array}{l}\mathrm{SSA}_{\mathrm{BET}} \\
{\left[\mathrm{m}^{2} / \mathrm{g}\right]}\end{array}$ & $\begin{array}{l}\mathrm{SSA}_{\text {geo }} \\
{\left[\mathrm{m}^{2} / \mathrm{g}\right]}\end{array}$ & $\begin{array}{c}r_{\text {geo }} \\
{\left[\mathrm{mol} / \mathrm{m}^{2} / \mathrm{s}\right]}\end{array}$ & $\begin{array}{c}\text { Time } \\
(t) \\
\text { [years] }\end{array}$ & $\begin{array}{c}\text { Amount } \\
\text { dissolved/(t) } \\
\text { [mol] }\end{array}$ & $\begin{array}{c}\text { Amount } \\
\text { dissolved/(t) } \\
{[\mathrm{kg}]}\end{array}$ & $\mathbf{R}_{\mathrm{CO} 2 \text { max }}$ & $\mathbf{R}_{\mathrm{CO} 2 \text { low }}$ \\
\hline 0.1 & 3.3 & 262.9 & 251.2 & 20.00 & $4.5 \mathrm{E}-11$ & 0.6 & 878 & 110 & 97 & 31 \\
\hline 0.25 & 3.6 & 284.9 & 91.7 & 8.00 & 4.1E-11 & 1.7 & 788 & 98 & 183 & 59 \\
\hline 0.5 & 4.0 & 323.9 & 42.8 & 4.00 & $3.8 \mathrm{E}-11$ & 3.5 & 918 & 115 & 284 & 91 \\
\hline 0.75 & 4.6 & 365.8 & 27.4 & 2.67 & $3.6 \mathrm{E}-11$ & 5.5 & 687 & 86 & 360 & 115 \\
\hline 1 & 5.1 & 410.2 & 20.0 & 2.00 & 3.5E-11 & 7.6 & 558 & 70 & 421 & 135 \\
\hline 2 & 7.6 & 605.2 & 9.3 & 1.00 & 3.3E-11 & 16.3 & 1628 & 203 & 600 & 192 \\
\hline 3 & 10.0 & 798.9 & 6.0 & 0.67 & $3.2 \mathrm{E}-11$ & 25.5 & 1022 & 128 & 713 & 228 \\
\hline 4 & 11.8 & 943.8 & 4.3 & 0.50 & 3.1E-11 & 34.9 & 637 & 80 & 783 & 250 \\
\hline 5 & 12.5 & 997.7 & 3.4 & 0.40 & 3.0E-11 & 44.7 & 389 & 49 & 825 & 264 \\
\hline 6 & 11.8 & 943.8 & 2.8 & 0.33 & 3.0E-11 & 54.6 & 232 & 29 & 851 & 272 \\
\hline 7 & 10.0 & 798.9 & 2.3 & 0.29 & 2.9E-11 & 64.7 & 133 & 17 & 866 & 277 \\
\hline 8 & 7.6 & 605.2 & 2.0 & 0.25 & $2.9 \mathrm{E}-11$ & 74.9 & 72 & 9 & 873 & 280 \\
\hline 9 & 5.1 & 410.2 & 1.8 & 0.22 & $2.8 \mathrm{E}-11$ & 85.3 & 37 & 5 & 878 & 281 \\
\hline 10 & 3.1 & 248.8 & 1.6 & 0.20 & $2.8 \mathrm{E}-11$ & 95.7 & 17 & 2 & 879 & 281 \\
\hline
\end{tabular}




\begin{tabular}{|c|c|c|c|c|c|c|c|c|c|c|}
\hline $\begin{array}{c}\text { grain } \\
\text { size } \\
{[\mu \mathrm{m}]}\end{array}$ & $\%$ & moles & $\begin{array}{l}\mathrm{SSA}_{\mathrm{BET}} \\
{\left[\mathrm{m}^{2} / \mathrm{g}\right]}\end{array}$ & $\begin{array}{l}\text { SSA }_{\text {geo }} \\
{\left[\mathrm{m}^{2} / \mathrm{g}\right]}\end{array}$ & $\begin{array}{c}r_{\text {geo }} \\
{\left[\mathrm{mol} / \mathrm{m}^{2} / \mathrm{s}\right]}\end{array}$ & $\begin{array}{l}\text { Time }(t) \\
\text { [years] }\end{array}$ & $\begin{array}{c}\text { Amount } \\
\text { dissolved } /(\mathrm{t}) \\
{[\mathrm{mol}]} \\
\end{array}$ & $\begin{array}{c}\text { Amount } \\
\text { dissolved/(t) } \\
{[\mathrm{kg}]} \\
\end{array}$ & $\mathbf{R}_{\mathrm{CO} 2 \text { max }}$ & $\mathbf{R}_{\mathrm{CO} 2 \text { low }}$ \\
\hline 0.1 & 4.2 & 251.2 & 20.00 & $4.5 \mathrm{E}-11$ & 333.6 & 0.6 & 3392 & 424 & 373 & 31 \\
\hline 0.15 & 5.1 & 160.8 & 13.33 & 4.3E-11 & 410.8 & 0.9 & 1159 & 145 & 501 & 59 \\
\hline 0.2 & 6.2 & 117.2 & 10.00 & $4.2 \mathrm{E}-11$ & 492.1 & 1.3 & 875 & 109 & 597 & 91 \\
\hline 0.25 & 7.2 & 91.7 & 8.00 & 4.1E-11 & 573.4 & 1.7 & 661 & 83 & 670 & 115 \\
\hline 0.3 & 8.1 & 75.0 & 6.67 & 4.0E-11 & 649.7 & 2.0 & 498 & 62 & 724 & 135 \\
\hline 0.35 & 9.0 & 63.3 & 5.71 & 3.9E-11 & 716.0 & 2.4 & 374 & 47 & 765 & 192 \\
\hline 0.4 & 9.6 & 54.7 & 5.00 & $3.9 \mathrm{E}-11$ & 767.5 & 2.8 & 279 & 35 & 796 & 228 \\
\hline 0.45 & 10.0 & 48.0 & 4.44 & $3.8 \mathrm{E}-11$ & 800.2 & 3.2 & 207 & 26 & 819 & 250 \\
\hline 0.5 & 10.1 & 42.8 & 4.00 & $3.8 \mathrm{E}-11$ & 811.4 & 3.5 & 153 & 19 & 836 & 264 \\
\hline 0.6 & 9.6 & 35.0 & 3.33 & 3.7E-11 & 767.5 & 4.3 & 188 & 24 & 856 & 272 \\
\hline 0.7 & 8.1 & 29.5 & 2.86 & 3.7E-11 & 649.7 & 5.1 & 108 & 13 & 868 & 277 \\
\hline 0.8 & 6.2 & 25.5 & 2.50 & $3.6 \mathrm{E}-11$ & 492.1 & 5.9 & 59 & 7 & 875 & 280 \\
\hline 0.9 & 4.2 & 22.4 & 2.22 & $3.6 \mathrm{E}-11$ & 333.6 & 6.8 & 30 & 4 & 878 & 281 \\
\hline 1 & 2.5 & 20.0 & 2.00 & $3.5 \mathrm{E}-11$ & 202.3 & 7.6 & 14 & 2 & 879 & 281 \\
\hline
\end{tabular}

Table S2: $\mathrm{CO}_{2}$ balance for different scenarios in $\mathrm{kg} \mathrm{CO}_{2} \mathrm{t}^{-1}$ of rock (Values used in figure 5). \% removal of annual GHG emissions denotes the cumulative removal after 7.6 years in \% of the annual Austrian GHG emissions ( $80 \mathrm{Mt} \mathrm{CO}_{2} \mathrm{e}$ ), if applied to an agricultural area of $1.902 \mathrm{M} \mathrm{ha}$.

\begin{tabular}{|c|c|c|c|c|c|c|}
\hline & \multicolumn{3}{|c|}{$\mathrm{Kg} \mathrm{CO}_{2} \mathrm{t}^{-1}$ after 7.6 years $[\mathrm{kg}]$} & \multicolumn{3}{|c|}{$\begin{array}{c}\text { \%removal of annual GHG } \\
\text { emissions } \\
\end{array}$} \\
\hline & $<100 \mu \mathrm{m}$ & $<10 \mu \mathrm{m}$ & $<1 \mu \mathrm{m}$ & $<100 \mu \mathrm{m}$ & $<10 \mu \mathrm{m}$ & $<1 \mu \mathrm{m}$ \\
\hline$R_{(\mathrm{CO}) \text { low }}-\mathrm{CO}_{2}$ emission (rail transport) & 21.8 & 78.0 & 125.1 & 5.2 & 18.5 & 29.7 \\
\hline$R_{(\mathrm{CO}) \text { low }}-\mathrm{CO}_{2}$ emission (road 20-40t) & 7.6 & 62.9 & 110.0 & 1.8 & 15.0 & 26.1 \\
\hline $\mathrm{R}_{(\mathrm{CO} 2) \text { low }}-\mathrm{CO}_{2}$ emission (road $<7.5 \mathrm{t}$ ) & -37.0 & 19.4 & 66.5 & -8.8 & 4.6 & 15.8 \\
\hline$R_{(\mathrm{CO}) \text { high }}-\mathrm{CO}_{2}$ emission (rail transport) & 105.2 & 364.4 & 723.1 & 25.0 & 86.6 & 171.9 \\
\hline$R_{(\mathrm{CO}) \text { high }}-\mathrm{CO}_{2}$ emission (road 20-40t) & 91.0 & 349.3 & 708.0 & 21.6 & 83.0 & 168.3 \\
\hline $\mathbf{R}_{(\mathrm{CO} 2) \text { high }}-\mathrm{CO}_{2}$ emission (road $<7.5 \mathrm{t}$ ) & 47.5 & 305.8 & 664.5 & 11.3 & 72.7 & 158.0 \\
\hline
\end{tabular}


1. Shrinking core model for calculation of dissolution times after (Hangx and Spiers. 2009)

$X_{\text {basalt }(t)}=\frac{d_{0}^{3}-d(t)^{3}}{d_{0}^{3}}$

$d(t)=d_{0}-2 R_{d i s s} \Omega t$

$X_{\text {basalt }}$ is the amount of basalt dissolved in time (t); $d_{0}$ is the initial grain size in $m$; $R_{\text {diss }}$ in our case is the dissolution rate normalized to geometric surface area $\left(\mathrm{SSA}_{\text {geo }}\right)$. as this model is based on spherical particles; $\Omega$ is the molar volume of basalt $\left(4.17 \times 10^{-5} \mathrm{~m}^{3} / \mathrm{mol}\right)$. Because the relationship between $\mathrm{SSA}_{\mathrm{BET}}$ and $\mathrm{SSA}_{\text {geo }}$ is not expected to be linear. $\mathrm{SSA}_{\mathrm{BET}}$ was calulcated. using equation 3 from (Brantley and Mellott. 2000) with

$\log \mathrm{SSA}_{\text {Bet }}\left(\mathrm{cm}^{2} / \mathrm{g}\right)=\mathrm{b}+\mathrm{m} \log (\mathrm{d})$

where $b$ is 5.3 and $m$ is -1.1 . Values are taken for olivine. Geometric surface area (SSA ${ }_{\text {geo }}$ ) was calculated for spherical particles after (Tester et al.. 1994):

$S S A_{G E O}=\frac{6}{d \rho}$

where $d$ is the diameter of the particle and $\rho$ is the density of basalt $\left(3 \mathrm{~g} / \mathrm{cm}^{3}\right)$. The roughness factor (Rf) can be calculated according to

$R f=\frac{S S A_{B E T}}{S S A_{G E O}}$

and the BET normalized dissolution rate $\left(\mathrm{r}_{\mathrm{BET}}\right)$ in our calculation derived from (Gudbrandsson et al.. 2011). at $3.5510^{-12} \mathrm{~mol} / \mathrm{m}^{2} / \mathrm{s}$ at pH 5.84 and $25^{\circ} \mathrm{C}$ was normalized to geometric surface area ( $\left.r_{\text {geo }}\right)$ through

$r_{g e o}=r_{B E T} * R f$

$r_{\text {geo }}$ was subsequently used to calculate the lifetime of a basalt grain after equation (2) for each fraction (see Table S1). To calculate the total amount of dissolved basalt, the shrinking core model was solved for each grain size at fixed time steps (table S1). Because the time steps were chosen for $97.5 \%$ dissolution, the resulting undissolved rest of $2.5 \%$ was added at each subsequent time step. 


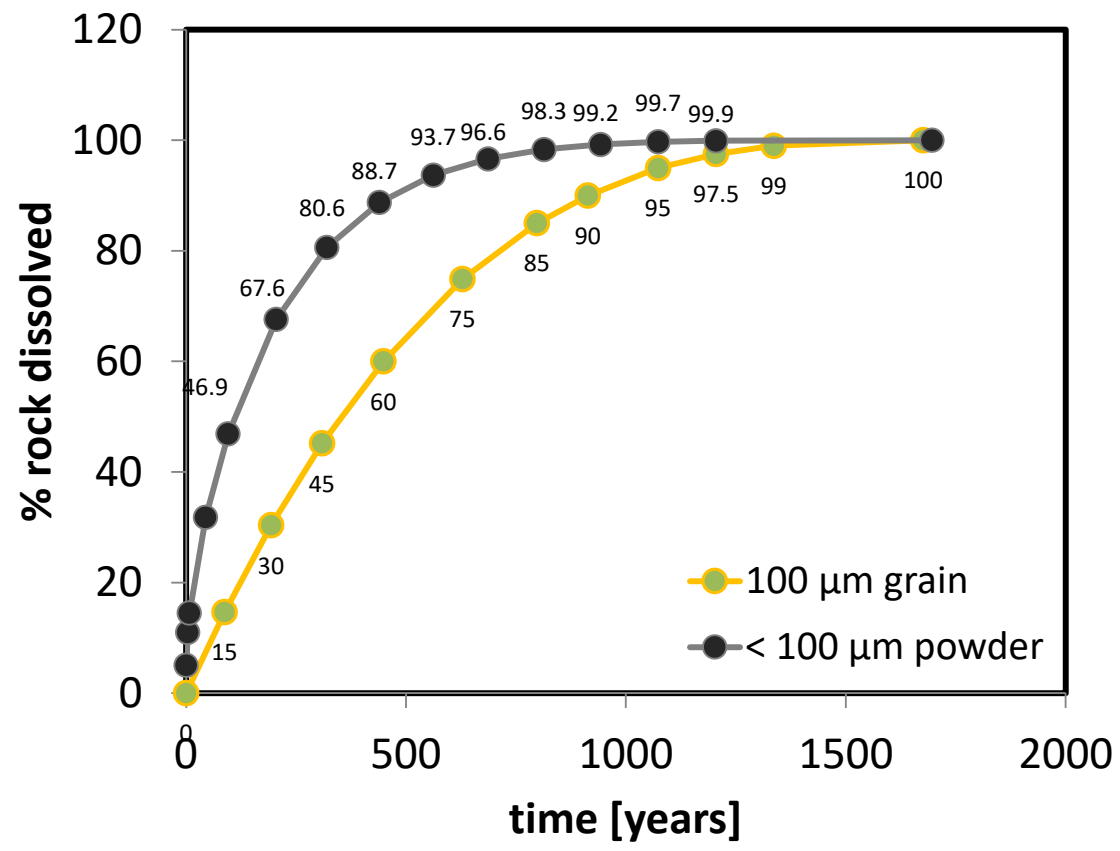

Figure S1: Time for dissolution of a $100 \mu \mathrm{m}$ basalt grain, calculated using the shrinking core model. Time for $97.5 \%$ dissolution of the grain is 1205 years. According to the chosen grain size distribution for the $<100 \mu \mathrm{m}$ basalt powder, 99,9\% of the powder will dissolve within this timeframe.

\section{Bibliography}

Brantley. S.L.. Mellott. N.P.. 2000. Surface area and porosity of primary silicate minerals. Am. Mineral. 85. 1767-1783. https://doi.org/https://doi.org/10.2138/am-2000-11-1220

Gudbrandsson. S.. Wolff-Boenisch. D.. Gislason. S.R.. Oelkers. E.H.. 2011. An experimental study of crystalline basalt dissolution from $2 \leqslant \mathrm{pH} \leqslant 11$ and temperatures from 5 to $75^{\circ} \mathrm{C}$. Geochim. Cosmochim. Acta 75. 5496-5509.

Hangx. S.J.T.. Spiers. C.J.. 2009. Coastal spreading of olivine to control atmospheric CO2 concentrations: A critical analysis of viability. Int. J. Greenh. Gas Control 3. 757-767.

Tester. J.W.. Worley. W.G.. Robinson. B.A.. Grigsby. C.O.. Feerer. J.L.. 1994. Correlating quartz dissolution kinetics in pure water from 25 to $625^{\circ} \mathrm{C}$. Geochim. Cosmochim. Acta 58. 2407-2420. https://doi.org/10.1016/0016-7037(94)90020-5 